\title{
EFFECTS OF STORM-WATER RUNOFF ON WATER QUALITY OF THE EDWARDS AQUIFER NEAR AUSTIN, TEXAS
}

By Freeman L. Andrews, Terry L. Schertz, Raymond M. Slade, Jr., and Jack Rawson

U.S. GEOLOGICAL SURVEY

Water-Resources Investigations Report 84-4124

Prepared in cooperation with the. CITY OF AUSTIN

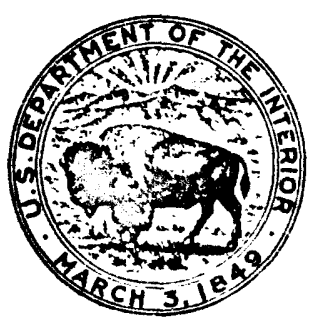




\section{CONTENTS}

Page

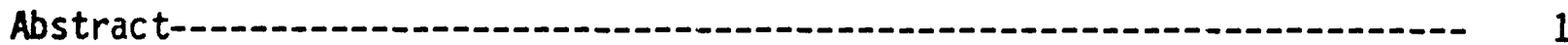

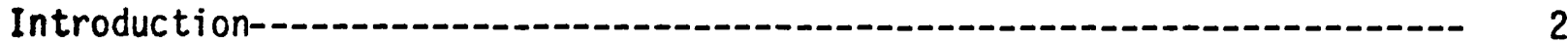

Purposes of study--.-_en 2

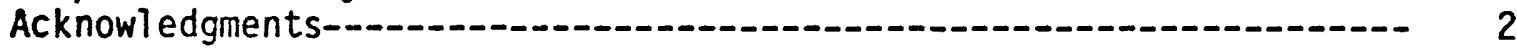

Description of study area--_-_-_- 2

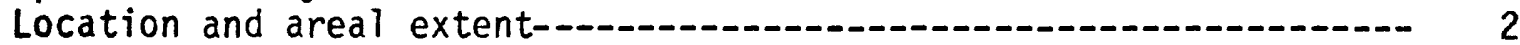

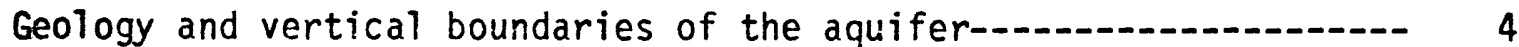

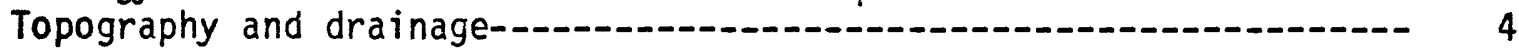

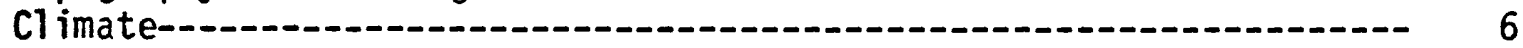

Recharge, movement, and discharge of ground water--.--.-- 6

Collection and statistical analysis of water-quality data-..........-. 9

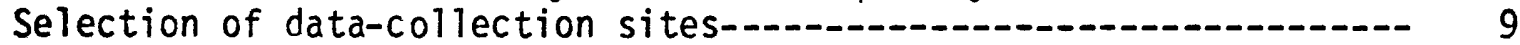

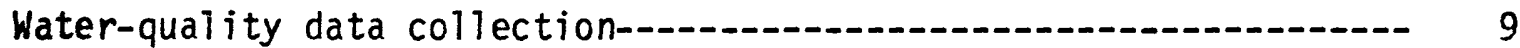

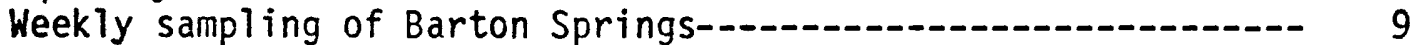

Fecal col iform and fecal streptococcal bacteria---.---.-- 10

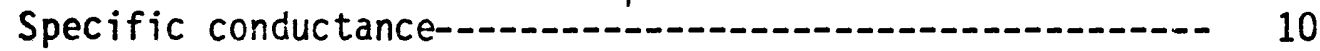

Total nitrogen species and total phosphorus------.----- 10

Sampling at selected sites during and after storms------------ 11

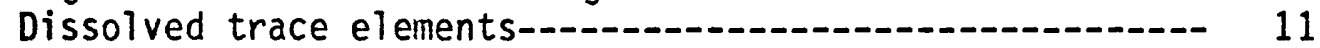

Total organic carbon and other non-volatile organic compounds----1-- 11



Effects of storm-water runoff on water quality-_-_-_-_-_- 12

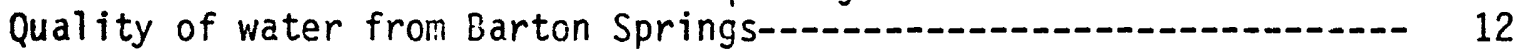



Specific conductance and related constituents and properties-- 14

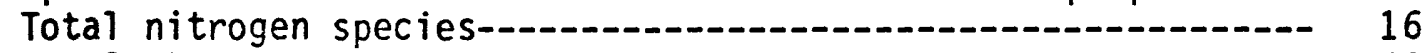

Total phosphorus-.-.-.-.- 20

Total organic carbon--.--.-- 20

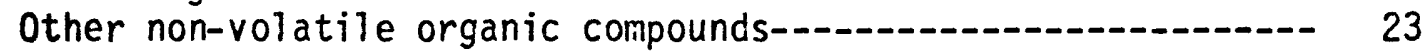

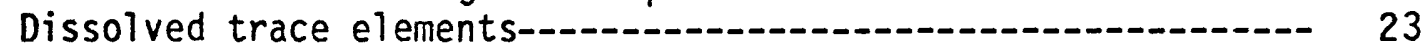

Relation of water quality of Barton Creek at Loop 360 to water

quality of Barton Springs-_.

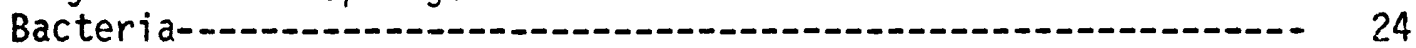

Specific conductance and related constituents and properties-- 24

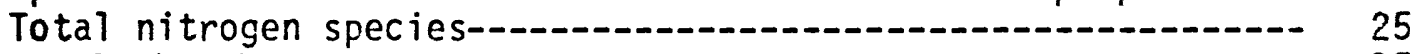

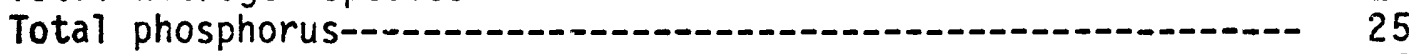

Total organic carbon--.-- 26

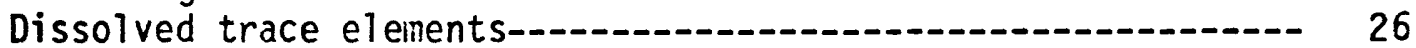

Water quality in selected wells--.--

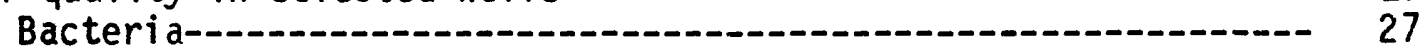

Specific conductance and related constituents and properties-- 27

Total nitrogen species--.-- 28

Total phosphorus- 29

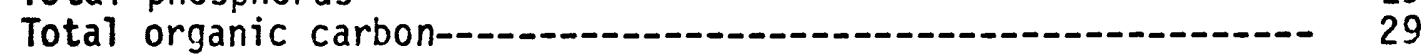

Dissolved trace elements-_- 29

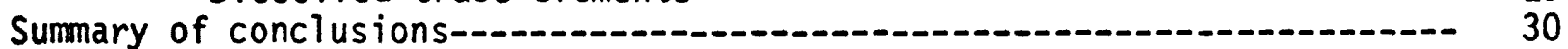

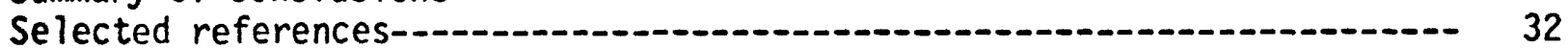

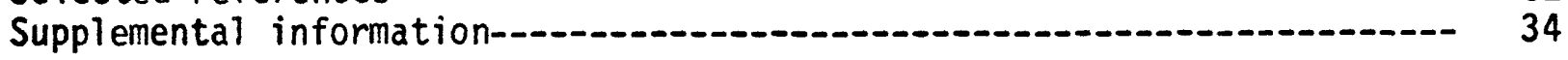




\section{ILLUSTRATIONS}

Page

Figure 1. Map showing location of study area and data-collection sites--_-

2. Map showing potentiometric levels in the Edwards aquifer, January 1981-_.

3-9. Graphs showing:

3. Precipitation, recharge to the aquifer, and discharge from Barton Springs-.-

4. Relation of quantities of recharge to the aquifer to densities and ratios of bacteria in samples from Barton Springs---

5. Relation of specific conductance of samples from Barton Springs to quantities of recharge to the aquifer---..---

6. Relation of concentrations of total organic nitrogen in samples from Barton Springs to quantities of recharge to the aquifer-an

7. Relation of concentrations of total ammonia nitrogen in samples from Barton Springs to quantities of recharge to the aquifer

8. Relation of concentrations of total nitrate nitrogen in samples from Barton Springs to quantities of recharge to the aquifer-antrations of total organic carbon in

9. Relation of concentrations of total organic carbon in samples from Barton Springs to quartities of recharge to the aquifer-

\section{TABLES}

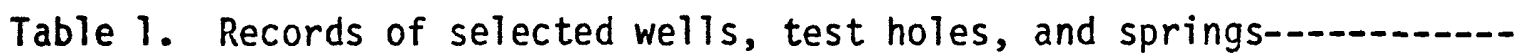

2. Source and significance of selected constituents and properties commonly reported in water analyses-...-...-..-

3. Summary of regulations for selected water-quality constituents and properties for public water systens---.-----

4. Water-quality data for Barton Springs at Austin (station 08155500)

5. Statistical summary of selected water-quality data for Barton Springs, October 1981 to September 1982-..-

6. Water-qual ity data for Barton Creek at Loop 360, Austin

7. Water-quality data for selected wells in the recharge 


\section{METRIC CONVERSIONS}

Factors for converting inch-pound units to metric equivalents are given in the following table:

\begin{tabular}{|c|c|c|}
\hline From & $\begin{array}{c}\text { Multiply } \\
\text { by }\end{array}$ & To obtain \\
\hline $\begin{array}{l}\text { acre-foot (acre-ft) } \\
\text { cubic foot per second }\left(\mathrm{ft}^{3} / \mathrm{s}\right) \\
\text { degree Fahrenheit }\left({ }^{\circ} \mathrm{F}\right) \\
\text { foot ( } \mathrm{ft} \text { ) } \\
\text { inch (in.) } \\
\text { micromho per centimeter at } \\
25^{\circ} \text { Celsius (umhos) } \\
\text { mile (mi) } \\
\text { square mile (mi2) }\end{array}$ & $\begin{array}{c}1,233.0 \\
0.02832 \\
5 / 9\left({ }^{\circ} \mathrm{F}-32\right) \\
0.3048 \\
25.4 \\
1.000 \\
\\
1.609 \\
2.590\end{array}$ & $\begin{array}{l}\text { cubic meter } \\
\text { cubic meter per second } \\
\text { degree Celsius }\left({ }^{\circ} \mathrm{C}\right) \\
\text { meter } \\
\text { millimeter } \\
\text { microsiemens per centimeter at } \\
25^{\circ} \text { Celsius } \\
\text { kilometer } \\
\text { square kilometer }\end{array}$ \\
\hline
\end{tabular}

National Geodetic Vertical Datum of 1929 (NGVD of 1929): A geodetic datum derived from a general adjustment of the first-order level nets of both the United States and Canada, formerly called "mean sea level." 


\title{
EFFECTS OF STORM-WATER RUNOFF ON WATER QUALITY OF THE EDWARDS AQUIFER NEAR AUSTIN, TEXAS
}

\section{By}

Freeman L. Andrews, Terry L. Schertz,

Raymond M. Slade, Jr., and Jack Rawson

\begin{abstract}
Analyses of samples collected from Barton Springs at approximately weekly intervals and from Barton Creek and five wells in the Austin area during selected storm-runoff periods generally show that recharge during storm runoff resulted in significant temporal and areal variations in the quality of ground water in the recharge zone of the Edwards aquifer. Recharge during storm runoff resulted in significant increases of bacterial densities in the ground water. Densities of fecal coliform bacteria in samples collected from Barton Springs, the major point of ground-water discharge, ranged from less than 1 colony per 100 milliliters during dry weather in November 1981 and January and August 1982 to 6,100 colonies per 100 milliliters during a storm in May 1982. Densities of fecal streptococcal bacteria ranged from 1 colony per 100 milliliters during dry weather in December 1981 to 11,000 colonies per 100 milliliters during a storm in May 1982.

Recharge during storm runoff resulted in significant decreases in the specific conductance and the concentration of total nitrate nitrogen in the ground water. Specific-conductance values of samples from Barton Springs ranged from 438 micromhos per centimeter at $25^{\circ}$ Celsius after a storm in October 1981 to 682 micromhos after a relatively long period of deficient rainfall in September 1982. The specific-conductance values and, thus, the mineralization of the ground water in the recharge zone generally were inversely related to the quantity of recharge. Nitrate nitrogen was the most prevalent form of nitrogen in the ground water. Concentrations of total nitrate nitrogen in samples from Barton Springs ranged from 0.51 milligram per liter after a storm in october 1981 to 1.6 milligrams per liter during dry weather in February and September 1982.
\end{abstract}

Although the values of these and other properties or constituents in ground water varied temporally and areally, available data indicate that the values of most of the major and minor elements in ground water in the recharge zone of the Edwards aquifer were significantly less than the primary maximum or secondary maximum contaminant leveis set by the U.S. Environmental Protection Agency for public water systems.

Bacteriological data for Barton Springs and selected wells indicate that the ground water in the aquifer is susceptible to bacterial pollution, especially during storm runoff. The water may require disinfection if used for drinking or culinary purposes. 


\section{INTRODUCTION}

Recharge to the Edwards aquifer is contributed partly by direct infiltration of precipitation but primarily by seepage from streams that cross the outcrop and have drainage basins that include rapidly developing urban areas. Currently (1984), the Edwards aquifer in the Austin area serves as a source of water supply for several incorporated areas, residential subdivisions, industries, and agricultural areas. The aquifer, which is a potential source of municipal supply for the city of Austin, also is the source of flow for Barton Springs. The springs are important recreation features in the Austin area and major sources of inflow to Town Lake.

Data collected from Barton Springs during 1979 and 1930 indicated that the densities of fecal coliform and fecal streptococcal bacteria in the water increased after significant storm runoff and recharge to the aquifer. These preliminary results provided presumptive evidence that bacterial pollution from urban areas was reaching and moving through the Edwards aquifer and caused increasing concern about the potential degradation of the quality of the ground water by urban development on or adjacent to the recharge zone of the aquifer.

\section{Purposes of Study}

A 1-year study by the U.S. Geological Survey in cooperation with the City of Austin was begun in October 1981 to determine the variations of selected indicator water-quality properties and constituents in samples from Barton Springs and from selected wells before and after significant recharge to the aquifer. The purposes of this report are to summarize the records of rainfall, recharge, and discharge for the Edwards aquifer in the Austin area; to provide statistical comparisons of water-quality data collected for Barton Springs before and after selected periods of significant recharge to the aquifer; and to analyze water-quality data collected from Barton Springs and selected wells.

\section{Acknowl edgments}

The assistance of property owners in providing access to their property, information concerning their wells, and use of wells for sampling is gratefully acknowledged. Appreciation is also extended to City of Austin officials for their assistance and cooperation.

\section{DESCRIPTION OF STUDY AREA \\ Location and Areal Extent}

The study area includes a part of the Edwards aquifer in Travis and Hays Counties in central Texas, most of which is hydraulicaliy connected with Barton Springs (fig. 1). The $155-\mathrm{mi}^{2}$ surface area is bounded on the north by the Colorado River (Town Lake), on the west by the limit of the Edwards Limestone outcrop, and on the south by the drainage divide between Onion Creek and the Blanco River, which also is a ground-water divide. The eastern boundary is the line that separates the freshwater and saline water, which has concentrations of $1,000 \mathrm{mg} / \mathrm{L}$ (milligrams per liter) or more of dissolved solids in the aquifer (locally known as the "bad-water line"). The northern and southern boundaries 


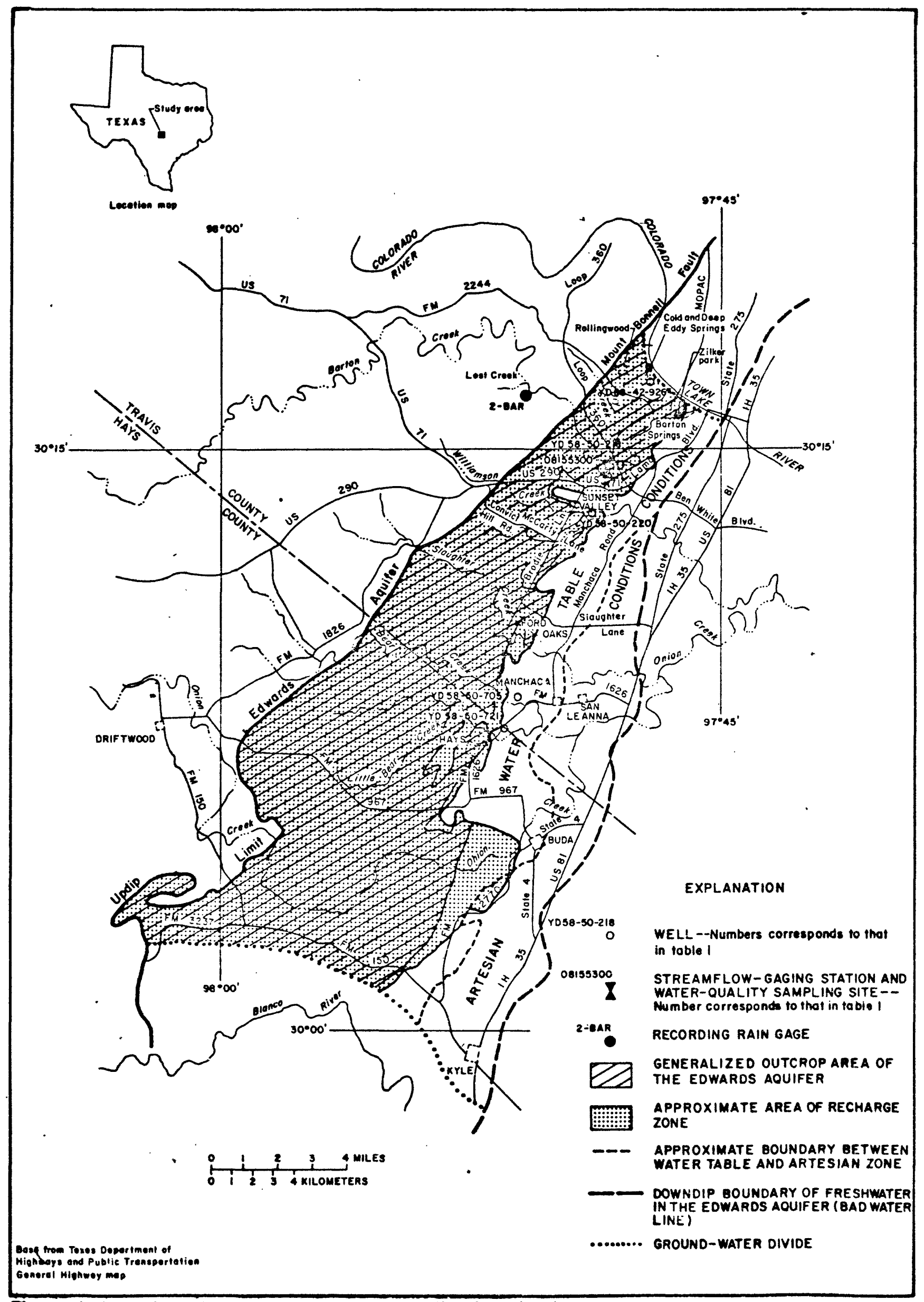


are hydrologic divides. The potentiometric surface of the aquifer generally is higher than the potentiometric surface along the bad-water line toward the east (fig. 2). Consequently, Barton Springs usually is not hydraulically connected with the subsurface part of the aquifer east of the bad-water line.

\section{Geology and Vertical Boundaries of the Aquifer}

The generalized geology and geologic structures that affect the occurrence and movement of ground water in the Edwards aquifer in the study area have been described by Brune and Duffin (1983) and by Ashworth (1983). For a detailed discussion of the geology of the area, readers are referred to these publications.

The Edwards aquifer in the study area consists of carbonate rocks of the Edwards and associated limestones of Cretaceous age that are hydraulically connected and includes in ascending order the Edwards Limestone and Georgetown Limestone. Because these formations are hydraulically connected, they are se1dom differentiated by drillers in the area.

The Edwards aquifer in the area consists of a water-table (unconfined) zone and an artesian (confined) zone (fig. 1). Throughout much of the watertable zone, outcrops of the Edwards and associated limestones are exposed at the surface, except along some of the streams where the limestones are covered by permeable alluvial material. Within the artesian zone area, the Edwards aquifer is overlain by the Del Rio Clay, which consists predominantly of clay and limestone with low permeability. Throughout the study area, the Edwards aquifer is underlain by the Walnut Formation (Brune and Duffin, 1983, p. 34), which consists predominantly of shale and limestone with low permeability.

\section{Topography and Drainage}

The study area extends from the Hill Country of central Texas eastward across the Balcones fault zone, a structural feature in the western one-half of the study area. The altitude of the land surface on the western edge of the aquifer ranges from about 1,000 ft above NGVD of 1929 in the southwest to about $500 \mathrm{ft}$ in the northeast along the Colorado River.

Soils overlying the hard limestone west of the Balcones fault zone generally are poorly developed, thin calcareous clays, clay loams, and stony clays. Soils on the soft limestones and shales of the Balcones fault zone generally are calcareous clays, clay loams, or silty clay loams. Soils on the flood plain and terraces of the Colorado River and its tributaries are sandy loams, silty clay loams, clay loams, and gravelly sands.

Principal streams and their tributaries that drain the study area include Barton Creek, Williamson Creek, Slaughter Creek, Bear Creek, Little Bear Creek, and Onion Creek (fig. 1). Most of these streams originate west of the study area and flow east to northeast across the Balcones fault zone toward the Colorado River east of the study area. Some of these streams are dry, except during storm runoff. Dry-weather flow in most of the other streams is sustained predominantly by municipal, domestic, and industrial return flows. Flow in the reach of Barton Creek near the Colorado River is sustained by Barton Springs. 


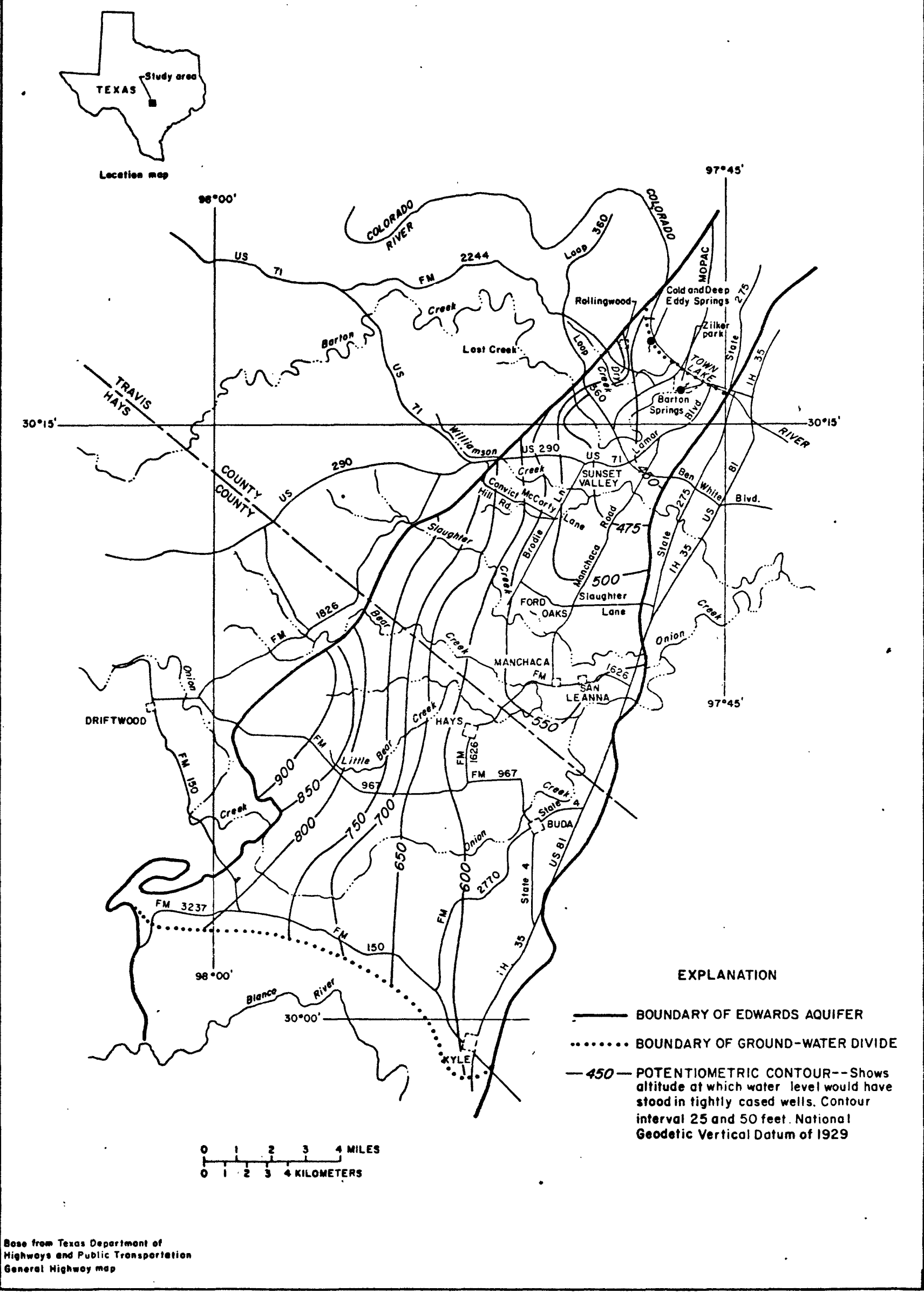

Figure 2.-Potentiometric levels in the Edwards aquifer, January 1981 
Flow from the major springs of Barton Springs is impounded temporarily by a detention dam. The resulting pool and surrounding park area serve as a major recreational facility.

\section{Climate}

The climate of the Austin area is humid subtropical with hot summers and mild winters. The average-annual temperature is about $68^{\circ} \mathrm{F}$. The mean-maximum temperature for July is about $95^{\circ} \mathrm{F}$, and the mean-minimum temperature for January is about $41^{\circ} \mathrm{F}$. Temperatures less than $32^{\circ} \mathrm{F}$ occur on an average of less than 25 days each year.

Long-term precipitation records collected by the National Weather Service at the Austin Municipal Airport, located about $4.5 \mathrm{mi}$ northeast of Barton Springs, have been summarized by Brune and Duffin (1983, p. 8). According to these records, the annual precipitation for this station averages about 33.5 in. These long-term records indicate that precipitation is fairly evenly distributed throughout the year; however, individual storms may occur in any season. The major storms usually occur during April-May and September-October.

As part of its hydrologic studies in the Austin urban area, the Geological Survey has installed and operates 26 recording precipitation gages, 16 of which are south of the Colorado River (Slade and others, 1983, p. 3). The gages are distributed throughout the area to measure total precipitation and to define precipitation intensities. The location of one of these gages (designated as 2-BAR in the Barton (reek watershed) whose records were used in this study of the Edwards aquifer, is shown in figure 1. The mean precipitation computed from the 16 gages in the Austin area south of the Colorado River was about 28 in. for the 1982 water year (October 1, 1981, to September 30, 1982). Individual station totals ranged from less than 20 in. at a station in the Onion Creek watershed to more than $32 \mathrm{in.}$ at a station in the Williamson Creek watershed.

\section{RECHARGE, MOVEMENT, AND DISCHARGE OF GROUND WATER}

Recharge to the Edwards aquifer in the Austin area occurs primarily by infiltration of surface water from streams that cross the Balcones fault zone and to a lesser extent by direct infiltration of precipitation on the outcrop. As part of a related study to determine the magnitude of recharge to the aquifer in the Austin area, streamflow stations were installed near the upstream and downstream boundaries of the reach of each of the six major streams that contribute recharge to the aquifer. Installation of these stations was completed by July 1979. The approximate boundaries of the recharge zone were verified in May 1980 by a study on five of the streams that cross the Balcones fault zone. A series of streamflow measurements were made to quantify the losses and to delineate the area where losses occurred.

The generalized boundaries of the recharge zone are delineated by dashes in figure 1 to indicate that they are approximations. The actual boundaries may deviate from those shown but should not greatly affect the results of this study. 
The total drainage area of the six major streams in and upstream from the recharge zone is about $360 \mathrm{mi}^{2}$, of which about $90 \mathrm{mi}^{2}$ is within the recharge zone. Drainage-area ratios and available precipitation and streamflow records for July 1979 through December 1982 indicate that about 85 percent of the total recharge occurs along the main channels of these streams in the recharge zone and that about 15 percent occurs along the channels of tributaries and by direct infiltration of precipitation on the intervening areas. The percentage of total recharge contributed by the watershed of each of the six streams during this period is shown in the following table:

\begin{tabular}{lc}
\hline \multicolumn{1}{c}{ Watershed } & Percent of total recharge \\
\hline Barton Creek & 28 \\
Williamson Creek & 6 \\
Slaughter Creek & 12 \\
Bear Creek & 10 \\
Little Bear Creek & 10 \\
Onion Creek & 34 \\
\hline
\end{tabular}

Daily-precipitation data for station 2-BAR in the Barton Creek watershed and daily-mean recharge to the Edwards aquifer for the 1982 water year are shown in figure 3 to illustrate the relationship between precipitation and recharge. These data show that the daily-mean recharge ranged froin about $4 \mathrm{ft}^{3} / \mathrm{s}$ during the predominantly dry weather in August and September 1982 to about $340 \mathrm{ft}^{3} / \mathrm{s}$ after a storm in May 1982. The recharge for the 1982 water year averaged 51 $\mathrm{ft}^{3} / \mathrm{s}$.

A network of steeply dipping faults and joints, especially in the Balcones fault zone; large caverns; and underground channels afford the rapid movement of ground water through the aquifer. These avenues for rapid movement of water through the recharge zone make this part of the Edwards aquifer in the Austin area particularly susceptible to pollution from natural or human sources during storm runoff. The direction of the ground-water movement, which can be inferred from figure 2, is generally to the east-northeast in the northern part of the aquifer and to the east in the southern part of the aquifer.

Discharge from the Edwards aquifer in the Austin area occurs primarily by springflow and to a much lesser extent by pumpage from wells. Several springs are located in topographic low areas near Town Lake in Austin. These include Barton Springs, located about $0.5 \mathrm{mi}$ upstream from the mouth of Barton Creek, and Cold and Deep Eddy Springs, located about $1.5 \mathrm{mi}$ northwest of Barton Springs (fig. 1). Several other springs are located along the bed of Barton Creek upstream from Barton Springs but flow only when ground-water levels reach the level of the streambed.

Discharge from Barton Springs, the fourth largest spring in Texas (Brune, 1981), has been measured periodically since 1894. In March 1978, a water-level recorder was installed on a well about $200 \mathrm{ft}$ from the main springs. Hourly records for this well are used to compute daily-mean discharges for the springs (Slade and others, 1980, 1981, 1982, 1983). The results of more than 700 discharge measurements and the records of daily-mean discharge after March 1978, supplemented by precipitation records from the National Weather Service station in Austin, have been used to estimate monthly-mean discharges for Barton Springs 

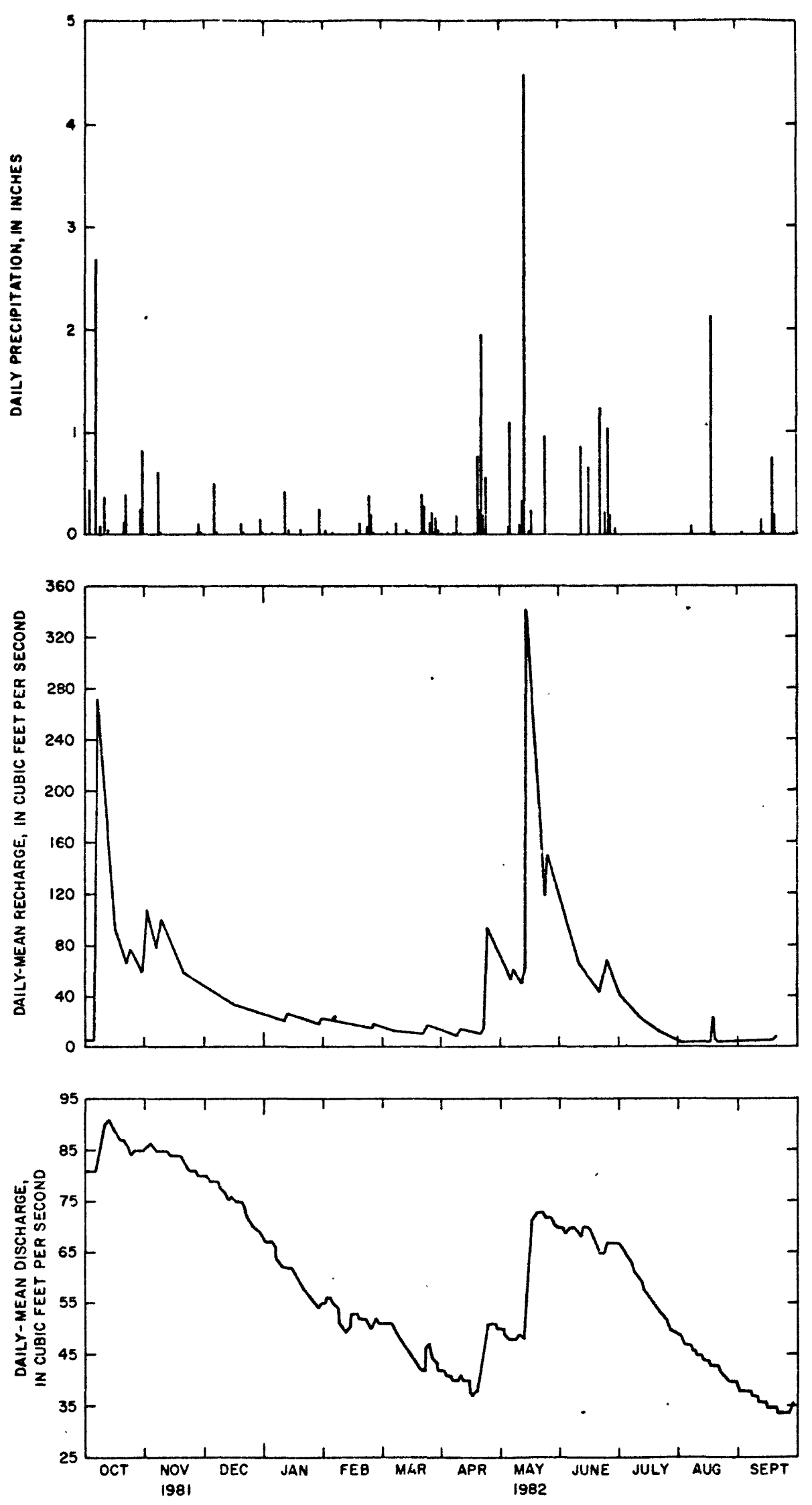

figure 3 -Precipitation, recharge to the aquifer, and discharge from Barton Spring

$-8-$ 
from 1917 to 1982. Based on these estimates, the monthly-mean discharge from Barton Springs has ranged from about $10 \mathrm{ft} 3 / \mathrm{s}$ to more than $130 \mathrm{ft} 3 / \mathrm{s}$ and has averaged about $50 \mathrm{ft} 3 / \mathrm{s}$. During the 1982 water year, the daily-mean discharge from the springs ranged from about $34 \mathrm{ft} / \mathrm{s}$ after dry weather in September 1982 to $91 \mathrm{ft}^{3} / \mathrm{s}$ after storm runoff in October 1981 and averaged about $59 \mathrm{ft} 3 / \mathrm{s} / \mathrm{fig}$. 3).

Cold and Deep Eddy Springs are in an area usually inundated by Town Lake. Based on several measurements, the discharge from these springs averages about $4 \mathrm{ft}^{3} / \mathrm{s}$.

Several hundred wells produce ground water from the Edwards aquifer in the study area. Only about 25 of these wells are major producers of viater for municipal, industrial, or irrigational uses. An inventory of records in files of the Texas Department of Water Resources indicates that total ground-water pumpage from the major wells during 1982 was about 2,900 acre-ft $\left(4.0 \mathrm{ft}^{3} / \mathrm{s}\right)$. The estimated total pumpage from other privately-owned wells that produce water mostly for domestic use and for livestock during 1982 was about 900 acre-ft $(1.2$ $\left.f t^{3} / s\right)$.

Based on the estimates of pumpage, estimates of flow from several small springs, and computations of flow from Barton Springs, the total discharge from the Edwards aquifer in the study area, averaged about $70 \mathrm{ft}^{3} / \mathrm{s}$ during the 1982 water year. Because of the large change in aquifer storage, mean discharge exceeded mean recharge for the 1982 water year. Water-budget analyses indicate a balance between long-term recharge and discharge values and indicate that leakage into or from the aquifer probably is minimal.

\section{COLLECTION AND STATISTICAL ANALYSIS OF WATER-QUALITY DATA Selection of Data-Collection Sites}

Because the flow from Barton Springs constitutes more than 80 percent of the total discharge from the Edwards aquifer and because of the importance of the springs as a recreation facility and as a source of inflow to Town Lake, the site of the springs was selected as the primary sampling site. The main springs discharge below the surface of a swimming pool formed by a detention dam on Barton Creek. Consequently, water samples were collected from a fracture adjacent to the main springs but above the water level of the pool.

Five secondary sampling sites were selected so that the water samples from the wells at the sites would represent recharge from drainage areas with different degrees of urban development. The location of the wells are shown in figure 1. Selected information, including the predominant land use of the drainage area in which each well is located, is given in table 1 (Supplemental Information section at back of report).

\section{Water-Quality Data Collection \\ Weekly Sampling of Barton Springs}

Water samples for the analysis of selected indicator properties or constituents were collected at approximately weekly intervals from Barton Springs. Analyses of these weekly samples included, but were not necessarily limited to, the following properties or constituents. 
Fecal coliform and fecal streptococcal bacteria

The coliform group of bacteria has been used as an indicator of the sanitary quality of water since the 1880 's. Fecal coliform bacteria are present in the intestines and feces of warm-blooded animals, and their occurrences in water reflect the presence of fecal contamination, which is the most likely source of pathogenic microorganisms (National Academy of Sciences, National Academy of Engineering, 1973, p. 58). Fecal streptococcal bacteria al so occur in the intestines of warm-blooded animals, and their presence in water is considered to verify fecal pollution (Geldreich and Kenner, 1969, p. 348). One potentially valuable application of the fecal streptococcal group is its correlation with the fecal coliform group as an aid in identifying sources of pollution. According to Geldreich and Kenner (1969, p. 349), the ratio of fecal coliform bacteria to fecal streptococcal bacteria in the feces of man and in fresh domestic wastewaters always is greater than 4.0 . Conversely, the ratio in the feces of farm animals, cats, dogs, and rodents; from separate storm-water systems; and farm-1 and drainage generally is less than 0.7. However, Geldreich and Kenner (1969, p. 349) caution that the use of the ratio for stream samples would be valid only during the initial 24-hour travel time from the point of pollution because of the death rate of the bacteria.

\section{Specific conductance}

This property is a measure of the ability of a water to conduct an electrical current and is related to the types and concentrations of ions in soiution. The specific concuctance of a solution increases as the ionic concentration increases. Consequently, the measurement of the specific conductance of a water sample is useful as a general indication of the dissolved-solids concentration and as a base for extrapolating the concentrations of the major ions when comprehensive analyses are available for some of the samples (Hem, 1970, p. 99).

Only a few samples from the Edwards aquifer were analyzed for dissolved solids and major inorganic ions during this study. Consequently, specific-conductance values will be used to indicate the variations in mineralization of samples collected during the study.

Total nitrogen species and total phosphorus

These elements are components of the metabolic wastes of humans and animals and of fertilizers and commonly may be indicative of the presence of pollution from these sources. However, these elements also may occur naturally in water as a result of leaching of soils and rocks and the decomposition of plants.

Nitrogen is a cyclic element and may occur in water in several forms. Some of the sources and significance of the various forms included in the analyses of weekly samples collected from Barton Springs during this study are summarized in table 2 (Supplemental Information section at back of report). 


\section{Sampling at Selected Sites During and After Storms}

Additional water samples from Barton Springs, from Barton Creek at Loop 360 (station 08155300, upstream from Barton Springs), and from five wells in the study area were collected during and after at least one significant storm (approximately 2 in. or more of precipitation) in the 1982 water year. Those indicator properties or constituents listed in the previous section were included in the analysis of these samples. Analyses of selected samples also included the following constituents.

\section{Dissolved trace elements}

These elements include those constituents, mostly cations, whose concentrations usually do not exceed $1 \mathrm{mg} / \mathrm{L}$. For the purpose of this report, the trace elements include arsenic, barium, cadmium, chromium, copper, iron, lead, manganese, mercury, selenium, silver, and zinc.

The occurrence of most of these trace elements in water is of concern primarily because of the potentially harmful effects of excessive concentrations on human, animal, and aquatic life. Regulations for these and other selected constituents and properties for public water systems are summarized in table 3 (Supplemental Information section at back of report).

Total organic carbon and other non-volatile organic compounds

Total organic carbon (TOC) is a nonspecific measure of non-volatile organic compounds in water. Organic carbon occurs naturally in humic material, algae, detritus, and other plant and animal materials. Consequently, organic carbon in water is not a direct indicator of pollution. However, concentrations much greater than about $1 \mathrm{mg} / \mathrm{L}$ in ground water and $5 \mathrm{mg} / \mathrm{L}$ in surface water may be presumptive evidence of the presence of pollution.

More than 4 million specific natural and synthetic organic compounds have been identified, of which several hundred have been identified in public water supplies. Trace concentrations of many of these organic compounds in water occur naturally, but others occur as results of human activity. The precision of organic-carbon measurements for concentrations less than $1 \mathrm{mg} / \mathrm{L}$ is poor. Specific procedures for most priority organic pollutants have detection limits that are from a thousand- to a million-fold less.

As a part of this study of the quality of ground water in the Austin area, several samples were screened for the presence of non-volatile organic compounds. This procedure consisted of an extraction of the water sample with methylene chloride, separation by gas chromatography, a scan by mass spectrometer detector, and a computerized search for each discernible peak of the unknown compound against a computer library of about 25,000 compounds. Most common non-volatile organic compounds, including many of the priority organic pollutants, can be identified by this method. 


\section{Method of Statistical Analysis}

Water-quality data for Barton Springs, the primary sampling site, were analyzed statistically to determine the effects of storm-water recharge on the quality of water in the Edwards aquifer. Methods selected for this analysis were those of the Statistical Analysis System (SAS) 1/ developed by the SAS Institute of Raleigh, North Carolina. The quantity of recharge to the Edwards aquifer during a particular storm depends primarily on the quantity and intensity of precipitation on the drainage areas of streams that cross the recharge zone and on antecedent precipitation. As a preliminary step in the statistical analysis, data were sorted into two groups on the basis of precipitation. Samples collected within 3 to 5 days after storms producing approximate 2 in. or more of precipitation were arbitrarily assigned to a group representing periods of significant recharge. Other samples were assigned to the group representing periods of insignificant recharge. The distribution of the data for selected properties or constituents in samples representing these groups were compared by using the SAS procedure SEASRS (Seasonal Rank Sum) Test, a modified version of the Mann-Whitney-Wilcoxan Rank Sum Test (Crawford and others, 1983). This procedure tests groups of data for significant differences at the 95-percent confidence interval.

\section{EFFECTS OF STORM-WATER RUNOFF ON WATER QUALITY}

Water-quality data for Barton Springs are shown in table 4 . Statistical summaries of selected properties or constituents for Barton Springs are shown in table 5. Hater-quality data for Barton Creek at Loop 360 (station 08155300) and five wells are shown in tables 6 and 7. Results of laboratory analyses for some properties or constituents were reported as "less than" $(<)$ values (tables $4,6,7)$, indicating that the values were less than the limit of detection or were based on non-ideal colony counts for bacteria (footnote "K"). Statistical analysis of data including "less than" values is virtually impossible; consequently, the "less than" values were converted to zero for the statistical summary of data for Barton Springs (table 5). Tables 5-7 are in the Supplemental Information section at the back of the report.

The following sections show that recharge of storm runoff generally resulted in significant temporal and areal variations in the quality of ground water in the recharge zone of the Edwards aquifer. Recharge by storm runoff in some instances resulted in a decrease in the concentrations of some of the water-quality constituents, but in others, it degraded the quality of the ground water. Differentiation of the sources or source areas of ground-water pollution are being addressed by related studies and will not be addressed in this report, except in very general terms.

\section{Quality of Water from Barton Springs}

$$
\text { Bacteria }
$$

Data in tables 4 and 5 and figure 4 show that the densities of fecal coliform bacteria in samples collected from Barton Springs during the study ranged

17 The use of trade names in this report is for identification only and does not constitute endorsement by the U.S. Geological Survey. 

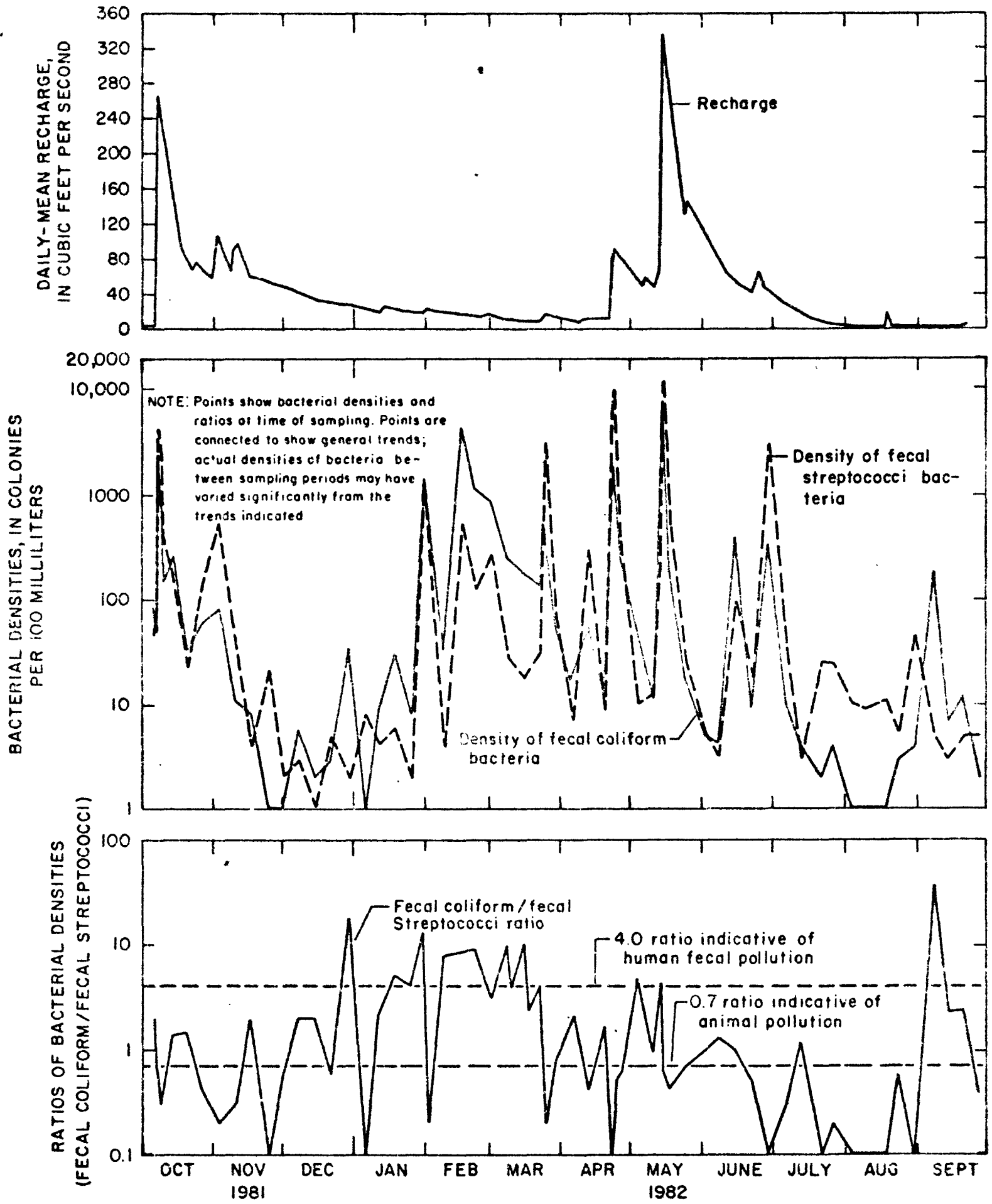

Figure 4.-Relation of quantities of recharge to the aquifer to densities and ratios of bacteria in samples from Barton Springs 
from less than $1 \mathrm{col} / 100 \mathrm{~mL}$ (colony per 100 milliliters) during dry weather in November 1981 and January and August 1982 to $6,100 \mathrm{col} / 100 \mathrm{~mL}$ during a storm in May 1982. Densities of fecal streptococcal bacteria ranged from 1 col/100 $\mathrm{mL}$ during dry weather in December 1981 to $11,000 \mathrm{col} / 100 \mathrm{~mL}$ during a storm in May 1982. Accumulated precipitation during each of three significant storms in October 1981 and April and May 1982 exceeded 2 in., and the densities of both groups of bacteria exceeded 1,000 col/100 mL. The densities of both groups of bacteria in samples collected before each of these storms were less than 100 c01/100 $\mathrm{mL}$. The bacterial densities peaked during or shortly after each storm and then decreased sharply within several days after the storm. When accumulated precipitation was less than about $1.5 \mathrm{in}$. for about a week or more, the densities of both groups of bacteria usually were less than $100 \mathrm{col} / 100 \mathrm{~mL}$ and commonly less than $10 \mathrm{col} / 100 \mathrm{~mL}$. An exception to this generalization was noted from late January to late March 1982, when a leak in a municipal sewer line was discovered within several hundred feet of the springs and in late June 1982. Barton Springs is the source of water for a municipal swimming pool. Fecal coliform bacterial counts during storm runoff and during the municipal sewer-line leak commonly exceeded $200 \mathrm{col} / 100 \mathrm{~mL}$, the maximum level considered safe for bathing water (U.S. Environmental Protection Agency, 1977a, p. 42).

During the three significant storms in October 1981 and April and May 1982 when recharge to the Edwards aquifer increased rapidiy and averaged more than $70 \mathrm{ft}^{3} / \mathrm{s}$, the ratio of fecal coliform bacteria to fecal streptococcal bacteria in most samples from Barton Springs was less than 0.7. This relation indicates that the principal sources of fecal pollution in recharge resulting from significant storms and moving rapidly through the aquifer were wastes from domestic and wild animals rather than from humans. The only other periods when the densities of both groups of bacteria exceeded $100 \mathrm{col} / 100 \mathrm{~mL}$ was from late January to late March 1982, when a leak in a municipal sewer line near Barton Springs was discovered, and in late June 1982. The ratio of fecal coliform bacteria to fecal streptococcal bacteria in most samples collected from the springs during January to March was greater than 4.0 , which is indicative of fecal pollution from humans. Statistical analysis verified at the 95-percent-confidence level a significant difference between the densities of bacteria in samples representing periods of significant recharge and in samples representing periods of insignificant recharge.

\section{Specific Conductance and Related Constituents and Properties}

Specific-conductance values of samples collected from Barton Springs averaged about 590 umhos and ranged from 438 umhos after a storm in October 1981 to 682 umhos after a relatively long period of deficient precipitation in September 1982. Data in table 4 and figure 5 generally show that specific conductance was related inversely to the quantity of recharge. The data also show that throughout prolonged periods of deficient precipitation the specific conductance increased steadily but decreased rapidly during storms. During early October 1981 before the onset of a significant storm, the specific conductance of water from the springs was 600 umhos. On October 13 after a significant storm when accumulated precipitation exceeded $4 \mathrm{in}$., the specific conductance decreased to 438 umhos and then began a steady trend upward (fig. 5). Several storms of relatively short duration resulted in small decreases in specific conductance during a few days from November 1981 to Apri1 1982, but the general upward trend continued. By April 19, 1982, the specific conductance had increased 


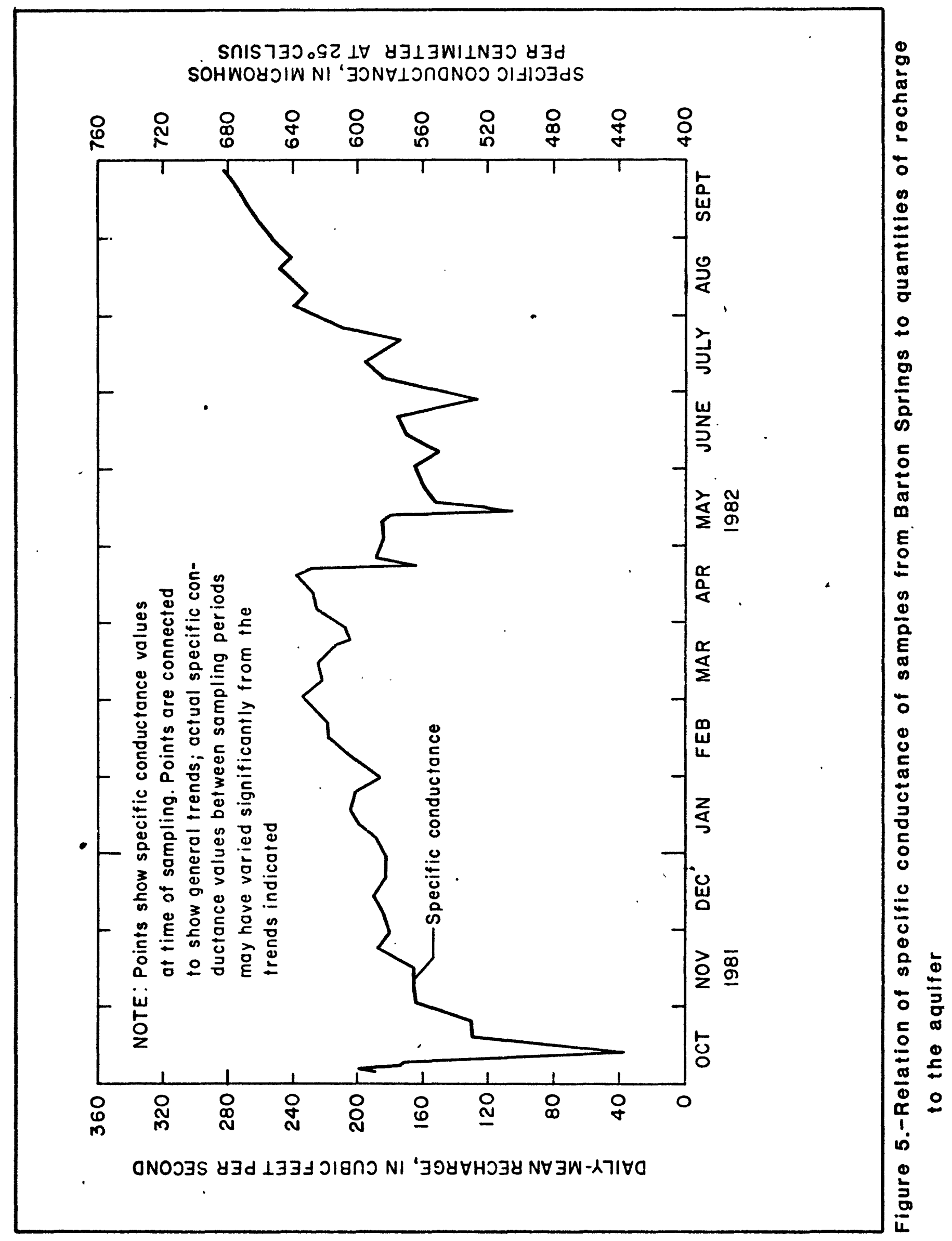


to 638 umhos. From April 19 to May 14, accumulated precipitation totaled more than 7 in. On May 14, the specific conductance decreased sharply to 505 umhos. After May 14, the specific conductance resumed a generally upward trend.

Statistical analysis verified at the 95-percent-confidence level a significant difference between the specific conductance of samples representing periods of significant recharge and of samples representing periods of insignificant recharge. During periods of significant precipitation on the drainage area, recharge was less mineralized than water in the aquifer. As this less mineralized recharge moved through the aquifer, it diluted the concentrations of the major inorganic ions in the water.

As noted in the section "Water-Quality Data Collection," the measurement of specific conductance of a water sample is useful as a general indication of the dissolved-solids concentration and as a base for extrapolating the concentrations of major ions when comprehensive analyses are available for some of the samples. Only a few samples collected during this study were analyzed for the concentrations of dissolved solids and major inorganic ions. However, 10 samples with a range in specific conductance from about 500 to 750 umhos have been collected from Barton Springs during other studies and have been analyzed for dissolved solids and major ions. On the basis of these analyses, approximate concentrations of selected constituents and properties including dissolved solids, dissolved chloride, dissolved sulfate, and total hardness were estimated for samples collected during this study and are summarized in the following table:

\begin{tabular}{llr}
\hline Constituent or property & $\begin{array}{l}\text { Range in concentration } \\
\text { (milifigrams per liter) }\end{array}$ & $\begin{array}{c}\text { Mean concentration } \\
\text { (miliigrams per liter) }\end{array}$ \\
\hline
\end{tabular}

Dissolved solids

Dissolved chloride

Dissolved sulfate

Total hardness

(as calcium carbonate)

$\begin{array}{rr}250-390 & 340 \\ 10-40 & 25 \\ 10-40 & 25 \\ 200-300 & 280\end{array}$

Comprehensive analyses of samples collected during this and related studies indicate that water from Barton Springs is of the calcium bicarbonate type and is very hard (greater than $180 \mathrm{mg} / \mathrm{L}$ hardness as calcium carbonate). A comparison of the estimated values for dissolved solids, chloride, and sulfate with values in table 3 indicates that concentrations of each of these constituents were less than the U.S. Environmental Protection Agency (1977b, p. 1714317147) secondary contaminant levels for public water systems.

\section{Total Nitrogen Species}

Laboratory analyses of samples for total nitrogen (analyses of unfiltered samples) included the determination of the concentrations of total nitrite plus nitrate nitrogen, total ammonia plus organic nitrogen, total ammonia nitrogen, and total nitrite nitrogen. The concentrations of nitrate nitrogen were calculated by subtracting nitrite concentrations from the determined nitrite plus nitrate concentrations, and the concentrations of organic nitrogen were calculated by subtracting ammonia concentrations from the determined concentrations 
of ammonia plus organic nitrogen. When the determined concentrations of nitrite and ammonia nitrogen were less than the detection limits, concentrations for nitrate and organic nitrogen were not reported by the laboratory. The limit of detection for nitrite was about $0.02 \mathrm{mg} / \mathrm{L}$ and for ammonia nitrogen it was about 0.06-0.07 mg/L. To facilitate statistical analyses of nitrogen data for this report when "less than" values were reported, the determined concentrations of nitrite plus nitrate nitrogen were assumed to be equivalent to concentrations of nitrate and the determined concentrations of ammonia plus organic nitrogen were assumed to be equivalent to concentrations of organic nitrogen. Estimated concentrations of nitrate and organic nitrogen based on this assumption, included in table 4 and quoted in subsequent sections of this report and in related figures, should be in error by no more than $0.02 \mathrm{mg} / \mathrm{L}$ for nitrate and no more than 0.06-0.07 $\mathrm{mg} / \mathrm{L}$ for organic nitrogen.

The concentrations of organic nitrogen in samples collected from Barton Springs averaged about $0.60 \mathrm{mg} / \mathrm{L}$ and ranged from $0.00 \mathrm{mg}$ - on June 1,1982 , after several storms in April and May, when recharge averaged more than 100 $\mathrm{ft}^{3} / \mathrm{s}$, to $2.6 \mathrm{mg} / \mathrm{L}$ on June 28 , 1982, after several storms in June, when recharge averaged more than $50 \mathrm{ft} / \mathrm{s}$ (fig. 6). The maximum concentration in samples collected before June 28, 1982, was $0.96 \mathrm{mg} / \mathrm{L}$. No direct relation was noted between concentrations of organic nitrogen and quantity of recharge from october 1981 to May 1982. However, the concentrations in samples near the onset of storms usually were greater than concentrations in antecedent or subsequent samples. This pattern of fluctuation, which is analogous to the "first-flush" pattern for streams, indicates that the source of most of the organic nitrogen from October 1981 to May 1982 was naturally occurring, decaying organic debris in the drainage area. During dry weather from late June through September 1982, when recharge to the aquifer was predominantly sustained by municipal, domestic, and industrial return flows, concentrations of organic nitrogen fluctuated erratically but usually were significantly greater than during antecedent periods. Concentrations during this period ranged from $2.6 \mathrm{mg} / \mathrm{L}$ on June 28 to $0.33 \mathrm{mg} / \mathrm{L}$ on September 13 and showed a general downward trend. Because of the erratic fluctuations, statistical analysis at the 95-percent-confidence level showed no significant difference between the concentrations of organic nitrogen in samples representing periods of significant recharge and in samples representing periods of insignificant recharge.

The concentrations of ammonia nitrogen averaged about $0.07 \mathrm{mg} / \mathrm{L}$ and ranged from less than $0.060 \mathrm{mg} / \mathrm{L}$ in many samples to $0.30 \mathrm{mg} / \mathrm{L}$ in a sample collected on March 15, 1982, during the period when a leak was discovered in a municipal sewer line near Barton Springs. No direct relation was noted between concentrations of ammonia nitrogen and quantity of recharge (fig. 7). However, a "first-flush" pattern was noted during the onset of some storms in October and November 1981 and April and May 1982. During a relatively dry period in August and September 1982, the concentrations varied erratically but showed a general upward trend. This upward trend corresponded to, but lagged the downward trend for organic nitrogen. This relation indicates that during the summer dryweather period when recharge usually was sustained by municipal, domestic, and industrial return flows, organic nitrogen in the recharge was partly oxidized to ammonia nitrogen once it reached the aquifer. Because of the erratic fluctuations, statistical analysis at the 95-percent-confidence level showed no significant difference between the concentrations of ammonia nitrogen in samples representing periods of significant recharge and in samples representing periods of insignificant recharge. 
\&3117 \& 8 S SW

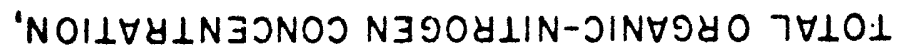

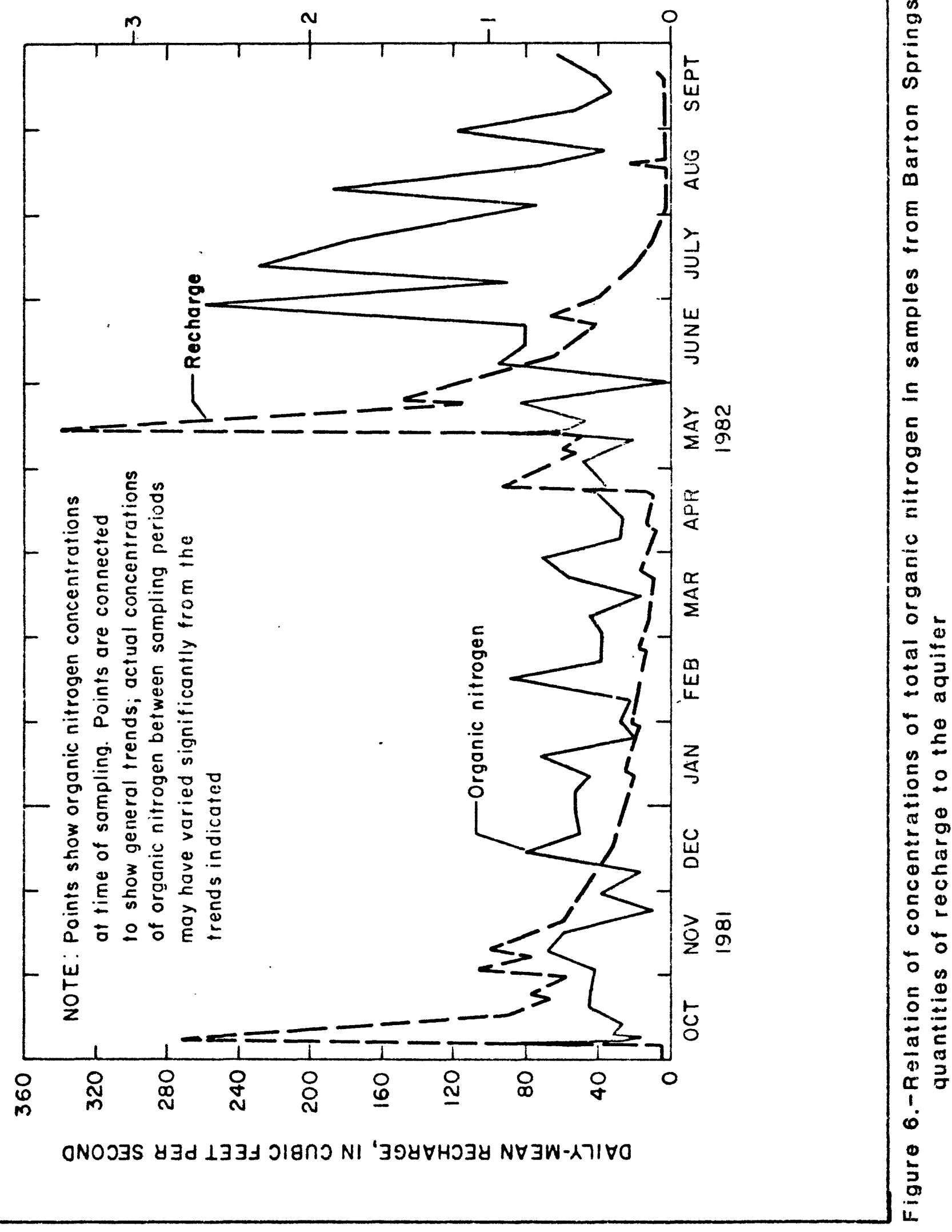




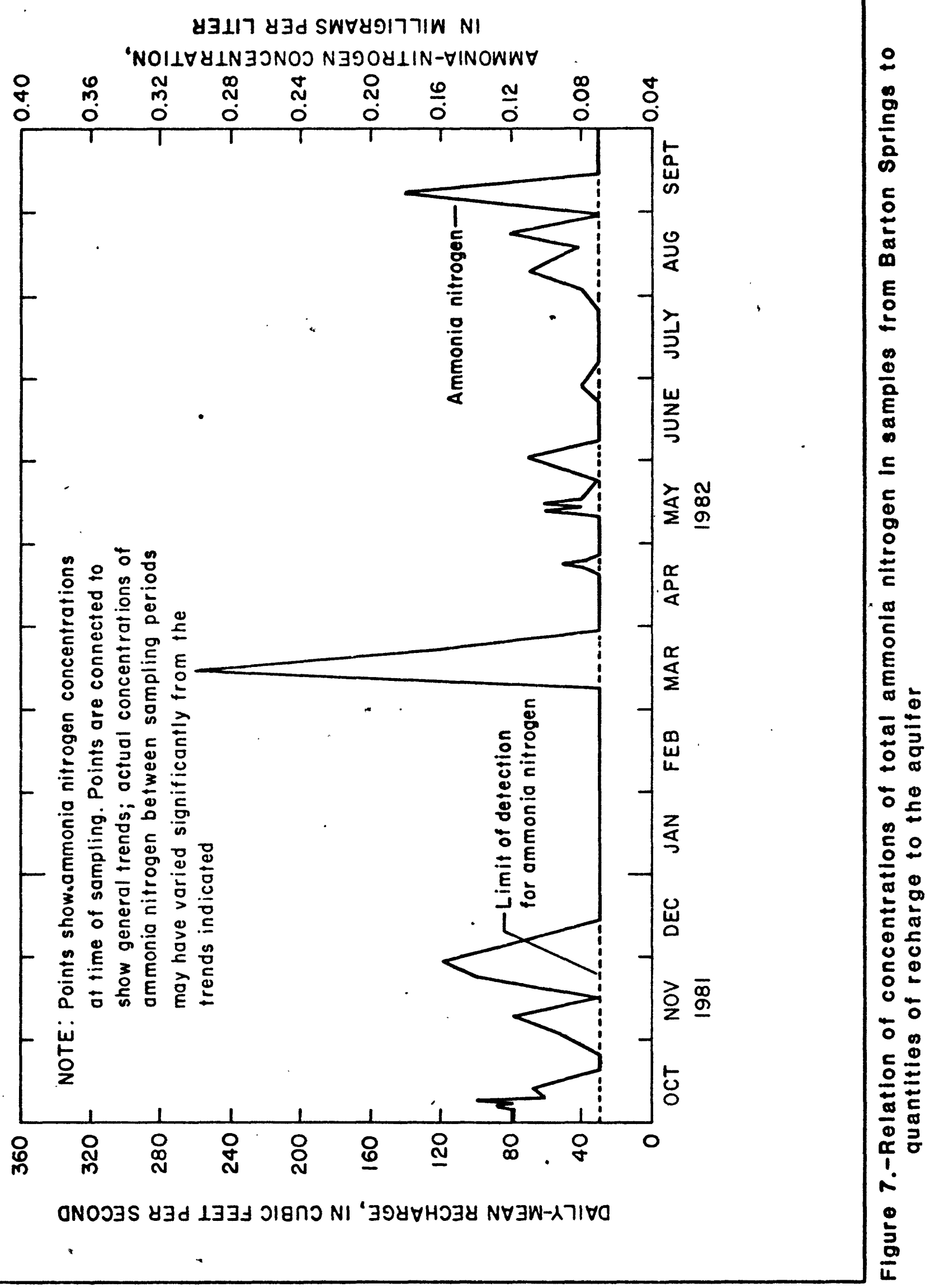


Nitrite nitrogen is very unstable in water. In oxygenated water, nitrite is rapidly oxidized to the more stable nitrate; in the absence of oxygen, it is rapidly reduced to a more stable form such as ammonia or molecular nitrogen. The maximum concentration of nitrite nitrogen in samples collected from Barton Springs was $0.03 \mathrm{mg} / \mathrm{L}$ after a storm in October 1981. Most other samples contained less than $0.02 \mathrm{mg} / \mathrm{L}$, the limit of detection.

Nitrate nitrogen was the most prevalent form of nitrogen in samples collected from Barton Springs, but the concentration in none of the samples exceeded the primary maximum contaminant level set by the U.S. Environmental Protection Agency (1976) for public water systems (table 3). Concentrations of nitrate nitrogen averaged about $1.3 \mathrm{mg} / \mathrm{L}$ and ranged from $0.51 \mathrm{mg} / \mathrm{L}$ after a storm in October 1981 to $1.6 \mathrm{mg} / \mathrm{L}$ after dry weather in February and September 1982. Data in figure 8 generally show that the concentrations of nitrate nitrogen were inversely related to the quantities of recharge. The data also show that throughout prolonged periods of deficient precipitation the nitratenitrogen concentration increased steadily but decreased rapidly after storms. Statistical analyses verified at the 90-percent-confidence level a significant difference between concentrations in samples representing periods of significant recharge and in samples representing periods of insignificant recharge. During periods of significant rainfall on the drainage area, recharge contained less nitrate nitrogen than water in the aquifer. As this recharge moved through the aquifer, it diluted the concentrations of nitrate nitrogen in the water.

\section{Total Phosphorus}

The concentrations of total phosphorus in samples collected from Barton Springs averaged about $0.020 \mathrm{mg} / \mathrm{L}$ and ranged from less than $0.010 \mathrm{mg} / \mathrm{L}$ in many samples to $0.25 \mathrm{mg} / \mathrm{L}$ in a sample collected on May 3, 1982. The concentrations varied erratically, especially during October 1981 and May and September 1982, but generally showed no relation to quantity of recharge. Statistical analysis verified at the 95-percent-confidence level no significant difference between concentrations in samples representing periods of significant recharge and in samples representing periods of insignificant recharge. Data collected from a site on Barton Creek upstream from Barton Springs (fig. 1, table 5) show that the concentration of total phosphorus in storm runoff that recharged the aquifer generally was significantly greater than concentrations in samples from the springs. These data indicate that phosphorus in the recharge was removed rather rapidly in the aquifer by processes such as sedimentation, adsorption, and precipitation of slightly soluble inorganic compounds.

\section{Total Organic Carbon}

The concentrations of TOC in samples collected from Barton Springs averaged about $0.6 \mathrm{mg} / \mathrm{L}$ and ranged from $0.0 \mathrm{mg} / \mathrm{L}$ during several periods of deficient precipitation in February, March, and April 1982 to $2.5 \mathrm{mg} / \mathrm{L}$ after storm runoff in May 1982 (fig. 9). The concentration in only one other sample, after a storm in October 1981 , exceeded $2.0 \mathrm{mg} / \mathrm{L}$. The concentration of TOC in samples collected at the onset of the May 1982 storm was $0.01 \mathrm{mg} / \mathrm{L}$ and at the onset of the October $1981 \mathrm{storm}$ was $0.03 \mathrm{mg} / \mathrm{L}$. The concentrations peaked rapidly during or shortly after the storms and then receded sharply. This "first-flush" effect indicates that the source of most of the TOC was decaying organic debris in the 


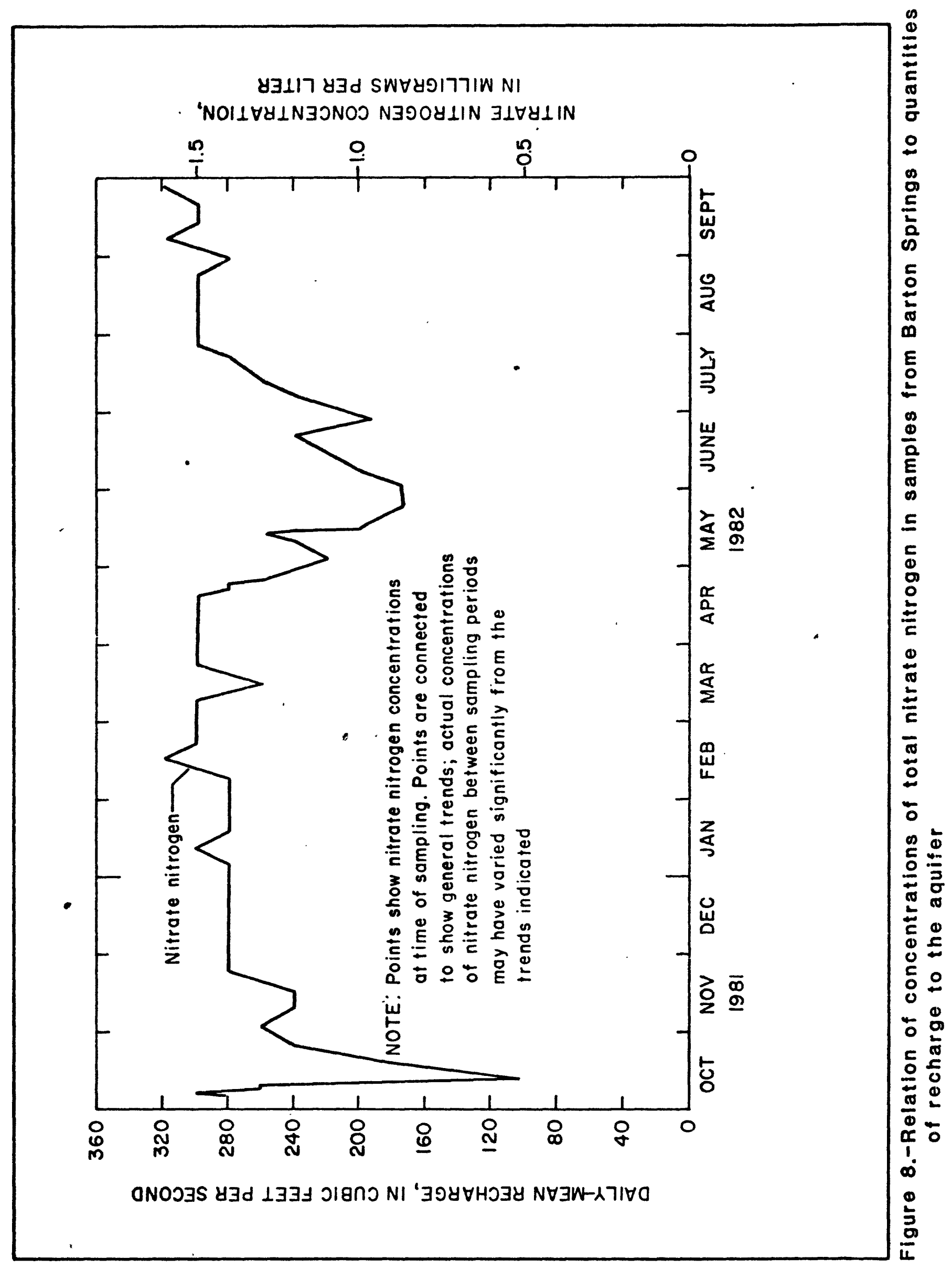




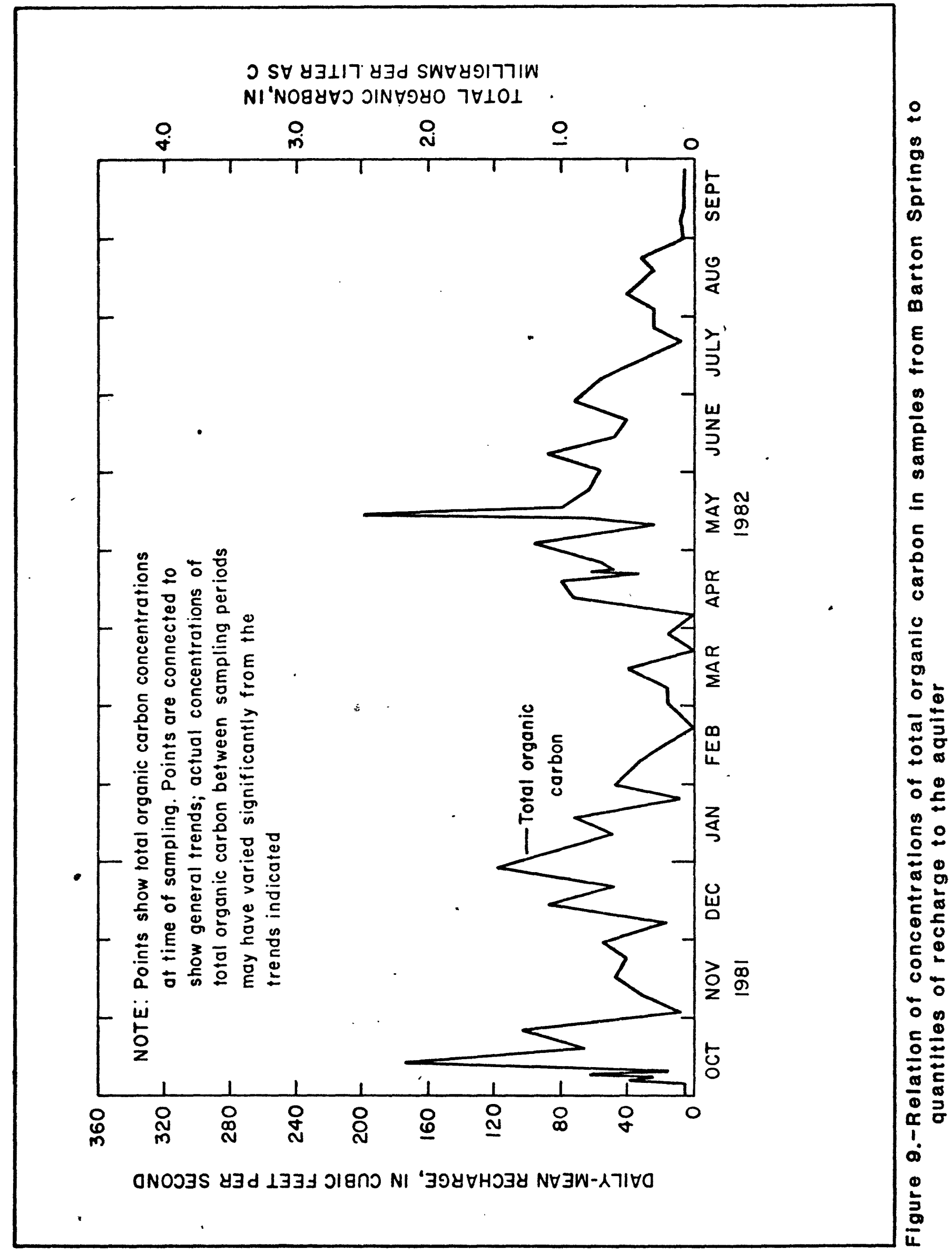


drainage area. However, the erratic variations in concentrations during dry weather from December 1981 to April 1982 indicate that part of the TOC probably was contributed by municipal, domestic, and industrial return flows. Because of these erratic variations, statistical analyses of the data indicate no significant difference at the 95-percent-confidence level between concentrations in samples representing periods of significant recharge and in samples representing periods of insignificant recharge.

\section{Other Non-Volatile Organic Compounds}

The concentrations of most non-volatile organic compounds, as determined on methylene-chloride extracts of a few samples collected from Barton Springs during storm runoff in October 1981 and April and May 1982, generally were either less than $5 \mu \mathrm{g} / \mathrm{L}$ or the limit of detection. The concentration of diethyl phthalate in a sample collected on October 7 was $120 \mu \mathrm{g} / \mathrm{L}$. Diethyl phthalate is widely used as a plasticizer in polyvinyl chloride (PVC) plastics and to a lesser extent as an industrial solvent, wetting agent, insecticides spray, or mosquito repellant. Although one of these uses in the drainage area may have been the source of the diethyl phthalate, concentrations in subsequent samples collected during storm runoff in April and May were less than $5 \mu \mathrm{g} / \mathrm{L}$.

\section{Dissolved Trace Elements}

The results of analyses for selected trace eiements in 12 samples collected from Barton Springs are shown in table 4. Analytical data for these samples, most of which were collected during storm runoff in october 1981 and April and May 1982, are summarized in the following table.

\begin{tabular}{|c|c|c|c|}
\hline $\begin{array}{l}\text { Dis } \\
\text { cons }\end{array}$ & $\begin{array}{l}\text { Minimum } \\
\text { value } \\
\text { (micrograns } \\
\text { per liter) }\end{array}$ & $\begin{array}{l}\text { Maximum } \\
\text { value } \\
\text { (micrograms } \\
\text { per liter) }\end{array}$ & $\begin{array}{l}\text { Primary maximum contaminant level } \\
\text { or secondary maximum contaminant } \\
\text { level for public water systems } \\
\text { (micrograms per liter) }\end{array}$ \\
\hline
\end{tabular}

\begin{tabular}{lcrr} 
Arsenic (As) & 0 & 2 & 50 \\
Barium (Ba) & 0 & 200 & 1,000 \\
Cadmium (Cd) & 0 & 1 & 10 \\
Chromium (Cr) & 0 & 10 & 50 \\
Copper (Cu) & $<1$ & 2 & 1,000 \\
Iron (Fe) & $<3$ & 60 & 300 \\
Lead (Pb) & $<1$ & 3 & 50 \\
Manganese (Mn) & 0 & 10 & 50 \\
Mercury (Hg) & 0.0 & $<0.1$ & 2 \\
Selenium (Se) & 0 & 1 & 10 \\
Silver (Ag) & 0 & $<1$ & 50 \\
Zinc (Zn) & $<3$ & 20 & 5,000 \\
\hline
\end{tabular}

This summary shows that the concentrations of none of the trace elements exceeded either the primary maximum contaminant levels or the secondary maximum contaminant levels set for public water systems by the U.S. Environmental Protection Agency (1976, 1977b). 


\section{Relation of Water Quality of Barton Creek at Loop 360 to Water Quality of Barton Springs}

Barton Creek, which drains an area of about $125 \mathrm{mi}^{2}$, contributes approximately 28 percent of the long-term recharge to the part of the Edwards aquifer hydraulically connected with Barton Springs. The downstream end of the recharge reach of Barton Creek is only about 0.5 mile west of of Barton Springs; consequently, the quality of water at the springs responds rapidly to changes in quality of recharge contributed by the creek. The drainage area in and upstream from the recharge zone is predominantly urban and rural (table 1). The quantity and quality of streamflow that originates in this drainage area are measured at gaging station 08155300, Barton Creek at Loop 360 (fig. 1). Water samples were collected periodically by an automatic sampler at this site during storm runoff on October 6-7, 1981, and on May 13-14, 1982. Water-quality data for this site (table 6) provide background information on the quality of recharge to the Edwards aquifer from Barton Creek during storm runoff.

\section{Bacteria}

The densities of fecal coliform bacteria in 10 samples collected from Barton Creek during storm runoff in October 1981 and May 1982 ranged from 5,100 to $80,000 \mathrm{col} / 100 \mathrm{~mL}$ and averaged about $40,000 \mathrm{col} / 100 \mathrm{~mL}$. The densities of fecal streptococcal Dacteria ranged from 4,000 to $86,000 \mathrm{col} / 100 \mathrm{~mL}$ and averaged about $40,000 \mathrm{col} / 100 \mathrm{~mL}$. The ratio of fecal coliform bacteria to fecal streptococcal bacteria averaged about 1.0, which indicates that the source of fecal pollution was predorinantly wastes from domestic and wild animals ratiner than from man.

A comparison of these data with bacteriological data for Barton Springs indicates that the densities of both groups of bacteria in the ground water discharged by Barton Springs increased rapidly as the bacteria-laden recharge from storm runoff entered the aquifer. The data also show that the peak densities of both groups of bacteria were significantly less in water from Barton Springs than in Barton Creek. This relation and the sharp decline of bacterial densities in the ground water after the initial peak indicate that bacteria in the recharge decreased rapidly due to dilution, sedimentation, adsorption, and die-off.

\section{Specific Conductance and Related Constituents and Properties}

The specific conductance of 10 samples collected from Barton Creek ranged from 141 to $366 \mu$ mhos and averaged about $220 \mu$ mhos. Values during both stormrunoff periods were greatest either shortly after the onset of the storm or toward the end of storm runoff. An overall comparison of these data with data for Barton Springs generally indicates that the streamflow resulting from storm runoff was less mineralized than ground water discharged by Barton Springs. As part of the water from storm runoff recharged and moved through the Edwards aquifer, a sharp decrease in the mineralization of water in the near-surface part of the aquifer occurred. As storm runoff ceases, the rate of recharge decreases and the mineralization of Barton Springs water increases sharply. Thereafter, as the rate of recharge decreased and as the recharge water was 
dispersed through the aquifer, the mineralization of the ground water increased gradually in response to the increased mineralization of the older water in the aquifer.

Based on the values of specific conductance, flood runoff from the Barton Creek drainage area was moderately hard (from 60 to $120 \mathrm{mg} / \mathrm{L}$ as calcium carbonate) and of the calcium bicarbonate type. The concentrations of dissolved solids averaged about $120 \mathrm{mg} / \mathrm{L}$, those of dissolved chloride averaged about 5 $\mathrm{mg} / \mathrm{L}$, and those of dissolved sulfate averaged about $15 \mathrm{mg} / \mathrm{L}$.

\section{Total Nitrogen Species}

The predominant nitrogen species in samples collected from Barton Creek during storm runoff was totai organic nitrogen. The concentrations of total organic nitrogen averaged about $1.8 \mathrm{mg} / \mathrm{L}$, those of total ammonia nitrogen averaged about $0.18 \mathrm{mg} / \mathrm{L}$, those of total nitrite nitrogen averaged about $0.05 \mathrm{mg} / \mathrm{L}$, and those of total nitrate nitrogen averaged about $0.18 \mathrm{mg} / \mathrm{L}$. Small variations in concentrations of each of these forms of nitrogen occurred during both periods of storm runoff. The concentrations of total organic nitrogen ranged from 0.62 to $3.3 \mathrm{mg} / \mathrm{L}$, those of total ammonia nitrogen from 0.090 to $0.250 \mathrm{mg} / \mathrm{L}$, and those of total nitrite nitrogen from less than 0.020 to $0.100 \mathrm{mg} / \mathrm{L}$. The maximum concentrations of each of these forms of nitrogen occurred in a sample collected during the peak of storm runoff on october 6 when the concentration of suspended solids was near maximum $(1,240 \mathrm{mg} / \mathrm{L})$. The minimum concentrations occurred in samples collected during the latter stages of each storm runoff when the concentrations of suspended solids were minimum $(135 \mathrm{mg} / \mathrm{L}$ for the October storm and $76 \mathrm{ing} / \mathrm{L}$ for the $M a_{\text {. storm). This }}$ relation indicates that most of the total organic nitrogen, total ammonia nitrogen, and total nitrite nitrogen in the storm runoff was in the suspended phase rather than in the dissolved phase. The concentrations of nitrate nitrogen ranged from 0.09 to about $0.37 \mathrm{mg} / \mathrm{L}$. The maximum concentration occurred in a sample collected near the cessation of storm runoff on May 14 when the concentration of suspended sclids was minimum $(76 \mathrm{mg} / \mathrm{L})$. This relation indicates that most of the nitrate nitrogen was in the dissolved phase.

The concentrations of organic nitrogen, ammonia nitrogen, and nitrite nitrogen in ground water discharged by Barton Springs during the october and May storm runoff were significantly less than concentrations in samples collected from Barton Creek; but the concentrations of nitrate nitrogen were significantly greater in the ground water. These relations indicate that most of the reduced forms of nitrogen in the sediment-laden recharge from storm runoff was removed both by sedimentation as the water entered the aquifer and by oxidation to the more stable form of nitrate nitrogen. These relations also indicate that the sources of most of the various forms of nitrogen in the ground water during storm runoff were naturally occurring organic debris and soils in the drainage area rather than domestic wastes.

\section{Total Phosphorus}

The concentrations of total phosphorus in storm-runoff samples from Barton Creek ranged from 0.040 to $0.73 \mathrm{mg} / \mathrm{L}$ and averaged $0.25 \mathrm{mg} / \mathrm{L}$. The maximum concentration occurred in a sample collected near the peak of storm runoff on 
May 13 when the concentration of suspended solids was maximum. The ininimurn concentrations during both periods occurred during the latter stages of storm runoff when the concentrations of suspended solids were minimum. This relation indicates that most of the total phosphorus was in the suspended phase.

The concentrations of total phosphorus in ground water discharged from Barton Springs during the October and May storm runoff were significantiy !ess than concentrations in samples collected from Barton creek. This relation indicates that most of the total phosphorus in the sediment-laden recharge from storm runoff was removed by processes such as sedimentation, precipitation, and adsorption as the water entered the aquifer. This relation also indicates that the sources of most of the phosphorus in the ground water during storm runoff were naturally occurring organic debris and soils in the drainage area rather than domestic wastes.

\section{Total Organic Carbon}

The concentrations of TOC in storm-runoff samples collected from Barton Creek ranged from 5.5 to $45 \mathrm{mg} / \mathrm{L}$ and averaged about $26 \mathrm{mg} / \mathrm{L}$. Hinimum concentrations were detected in samples collected during the latter stages of storm runoff when the concentrations of suspended solids were minimum. The concentrations were much greater in samples collected during the initial flush or near the peaks of storm runoff when the concentrations of suspended solids increased. This relation indicates that most of the TOC was in the suspended phase.

The concentrations of TOC in ground water discharged from Barton Springs during storm runoff were significantly less than concentrations in samples collected from Barton creek. This relation indicates that most of the TOC in the sediment-laden recharge from storm runoff was removed by processes such as sedimentation, oxidation, and adsorption as the water entered the aquifer. This relation also indicates that the source of the TOC in the ground water during storm runoff was naturally occurring organic debris and soils in the drainage area.

\section{Dissolved Trace Elements}

The concentrations of most of the dissolved trace elements in three samples collected from Barton Creek during the october storm runoff were less or only slightly greater than the limit of detection and were significantly less than the primary maximum contaminant level or secondary maximum contaninant level set by the U.S. Environmental Protection Agency (1976, 1977b) for public water systems.

The concentrations of most of the trace elements in ground water discharged from Barton Springs during the October storm runoff did not differ significantiy from concentrations in samples collected from Barton Creek. The concentrations of dissolved iron during the october storm runoff averaged less than $20 \mu \mathrm{g} / \mathrm{L}$ in samples from Earton Creek and more than $40 \mu \mathrm{g} / \mathrm{L}$ in samples from Barton Springs. This relation indicates that the principal source of iron in the ground water was rocks of the aquifer. 
Water Quality in Selected Hells

Water-quality data for five selected wells that are completed in the Edwards aquifer in the Austin area are shown in table 7 . Location of the wells is shown in figure 1, and descriptive information for the wells is included in table 1. Several samples were collected from each well during a storm in either April or May 1982 when precipitation exceeded 2 in. (fig. 3).

\section{Bacteria}

The average densities of fecal coliform bacteria in samples collected from these five wells during storm runoff in April or May ranged from less than 1 col/100 mL (wells YD-58-50-220 and YD-58-50-721) to about $400 \mathrm{col} / 100 \mathrm{~mL}$ (well YD-58-50-705). The average densities of fecal streptococcal bacteria ranged from less than $1 \mathrm{col} / 100 \mathrm{~mL}$ (well $\mathrm{YD}-58-50-721$ ) to more than $30,000 \mathrm{col} / 100 \mathrm{~mL}$ (well YD-58-42-926). The densities of fecal coliform bacteria in samples collected from well YD-58-50-705 during the storm runoff in May ranged from 1 to $1,200 \mathrm{col} / 100 \mathrm{~mL}$. The densities of fecal streptococcal bacteria in samples collected from well YD-58-42-926 during the storm runoff in April ranged from 18,000 to $44,000 \mathrm{col} / 100 \mathrm{~mL}$. The ratio of fecal coliform bacteria to fecal streptococcal bacteria in samples from these wells were less than 0.5 , which indicates that the source of the fecal pollution was wastes from animals rather than from humans. Well YD-58-42-926 is located in the drainage area of Dry Creek (fig. 1), which is predominantly a residential area. Well YD-58-50-705 is located in the drainage area of Bear Creek, which is predominantly an urban area. Data for samples from these wells and from Barton Springs indicate that the water in the recharge zone of the Edwards aquifer in the Austin area is susceptible to bacterial pollution, especially during storm runoff, and that the water may require disinfection if used for drinking or culinary purposes.

\section{Specific Conductance and Related Constituents ar.d Properties}

The average specific conductance of samples collected from an individual well during storm runoff in April or May ranged from about 480 umhos (well YD-58-50-218) to 580 umhos (well YD-58-50-220). The specific conductance of an individual sample ranged from $454 \mu$ mhos (well YD-58-50-705) to $583 \mu$ mhos (well YD-58-50-220). The largest variations in specific conductance of samples from an individual well were from 454 to 561 umhos (well YD-58-50-705) and from 458 to 506 umhos (well YD-58-50-218). We1l YD-58-50-705 is located in the drainage area of Bear Creek, a predominantly urban area; and well YD-58-50-218 is located in the drainage area of Barton Creek, a predominantly urban and rural area. The variations in specific conductance of samples from none of the other wells exceeded 15 umhos. Data from the two wells in which significant variations of specific conductance occurred and from Barton Springs indicate that recharge to the Edwards aquifer during storm runoff generally resulted in a decrease in mineralization of water in the aquifer. On the basis of specific conductance of samples collected from wells during this study and of comprehensive analyses of samples collected from these and near-by wells during previous and on-going studies, ground water in the recharge zone of the Edwards aquifer is very hard (greater than $180 \mathrm{mg} / \mathrm{L}$ hardness as calcium carbonate) and the calcium bicarbonate type. Concentrations of dissolved solids, chloride, and sulfate in the water varied both temporally and areally. On the basis of specific conductance 
of samples collected from wells during storm runoff and from Barton Springs at approximately weekly intervals, the concentrations of dissolved solids, chloride, and sulfate in water throughout the recharge zone of the Edivards aquifer in the Austin area averaged less than $340 \mathrm{mg} / \mathrm{L}, 25 \mathrm{mg} / \mathrm{L}$, and $25 \mathrm{mg} / \mathrm{L}$, respectively. The concentration of each of these constituents are much less than the secondary maximum contaminant levels set by the U.S. Environmental Protection Agency for public water systems (table 3 ).

\section{Total Nitrogen Species}

The average concentrations of total organic nitrogen in samples collected from individual wells during storm runoff in April and llay ranged from 0.37 $\mathrm{mg} / \mathrm{L}$ (wel1 YD-58-42-926) to $1.0 \mathrm{mg} / \mathrm{L}$ (well YD-58-50-218). The largest ranges in concentrations of total organic nitrogen in samples from an individual well were from 0.43 to $1.0 \mathrm{mg} / \mathrm{L}$ (well $\mathrm{YD}-58-50-705$ ) and from 0.42 to $0.97 \mathrm{mg} / \mathrm{L}$ (well YD-58-50-721). Well YD-58-50-705 is located in the predominantly urban area of Bear Creek; well YD-58-50-721 is located in the predominantly rural area of Little Bear Creek. Data for samples from these wells and from Barton Springs indicate that significant temporal and areal variation during storm runoff occurred throughout the recharge zone of the aquifer.

The temporal and areal variations in concentrations of total ammonia nitrogen and total nitrite nitrogen were insignificant. The average arnmonia nitrogen concentrations in samples collected from an individual well during storm runoff ranged from about 0.060 to $0.090 \mathrm{mg} / \mathrm{L}$. The largest range in concentrations in samples from one well was from 0.060 to $0.10 \mathrm{mg} / \mathrm{L}$ (we11 YD-58-50-218). The concentrations of nitrite nitrogen in all samples were less than the limit of detection (less than $0.020 \mathrm{mg} / \mathrm{L}$ ). These data indicate that most of the ammonia nitrogen and nitrite nitrogen contributed during recharge by storm runoff was rapidly adsorbed by the rocks of the aquifer or was oxidized to the more stable nitrate form of nitrogen.

The predominant form of nitrogen in water from all the wells except well YD-58-50-218 was total nitrate nitrogen. The average concentrations of nitrate nitrogen in samples collected from an individua? well ranged from about 0.47 $\mathrm{mg} / \mathrm{L}$ (wel1 YD-58-50-218) to $2.1 \mathrm{mg} / \mathrm{L}$ (well YD-58-50-220). The largest ranges in concentrations in samples from an individual well were from about 0.12 to 1.1 $\mathrm{mg} / \mathrm{L}$ (well YD-58-50-721) and from about 0.72 to $1.4 \mathrm{mg} / \mathrm{L}$ (well YD-58-50-705). Well YD-58-50-721 is located in the predominantly rural drainage area of Little Bear Creek; and well YD-58-50-705 is located in the predominantly urban drainage area of Bear Creek. Data for samples from these wells and from Barton Springs show that the concentrations of nitrate nitrogen in water in the recharge zone of the Edwards aquifer during storm runoff were much less variable than concentrations of organic nitrogen. On the basis of data for samples from these wells and from Barton Springs, the concentrations of total nitrate nitrogen in water throughout the recharge zone of the Edwards aquifer in the Austin area were well within the $10 \mathrm{mg} / \mathrm{L}$ primary maximum contaminant level set by the U.S. Environmental Protection Agency for public water systems (table 3 ). 


\section{Total Phosphorus}

The average concentrations of total phosphorus in samples collected from an individual well during storm runoff ranged from about $0.010 \mathrm{mg} / \mathrm{L}$ (well YD-58-50-220 and well YD-58-42-926) to $0.050 \mathrm{mg} / \mathrm{L}$ (well YD-58-50-218). The 1 argest range in concentrations of total phosphorus in samples from an individual well was from 0.030 to $0.080 \mathrm{mg} / \mathrm{L}$ (well YD-58-50-218). Data for samples from these wells and from Barton Springs indicate that most of the total phosphorus contributed during storm runoff was removed by sedimentation and adsorption by the rocks of the aquifer.

\section{Total Organic Carbon}

The concentration of TOC in samples from only one well (well YD-58-50-218) exceeded $1.0 \mathrm{mg} / \mathrm{L}$. The concentrations of TOC in samples from well YD-58-5C-218 in the urban and rural drainage area of Barton Creek ranged from 1.7 to $36 \mathrm{mg} / \mathrm{L}$ and averaged about $15 \mathrm{mg} / \mathrm{L}$ during storm runoff in May. During this period, the concentrations of TOC in samples collected from Barton Creek at Loop 360 averaged about $19 \mathrm{mg} / \mathrm{L}$ and those from Barton Springs averaged about $1.6 \mathrm{mg} / \mathrm{L}$. This relation indicates that large quantities of TOC in the sediment-laden recharge that entered the aquifer during storm runoff were rapidly removed by processes such as sedimentation, oxidation, and adsorption as the water moved through the aquifer.

\section{Dissolved Trace Elements}

None of the concentrations of dissolved trace elements (arsenic, barium, cadmium, chromium, copper, iron, lead, manganese, mercury, selenium, silver, and zinc) in samples collected from wells during storm runoff in April or May 1982 exceeded the primary maximum contaminant levels or secondary maximium contaminant levels set by the U.S. Environmental Protection Agency (1976, 1977b) for public water systems (table 3 ).

Concentrations of most of these trace elements in many of the samples were near or less than the limits of detection. However, small but significant temporal and areal variations in the concentrations of some of the elements occurred during storm runoff. The average concentrations of dissolved copper in samples collected from an individual well ranged from about $2 \mu \mathrm{S} / \mathrm{L}$ (well $\mathrm{YD}-58-50-721$ ) to more than $80 \mu \mathrm{g} / \mathrm{L}$ (well $\mathrm{YD}-58-50-218$ ). The average concentrations of dissolved lead ranged from less than $1 \mu \mathrm{g} / \mathrm{L}$ (well $\mathrm{YD}-58-50-220$ ) to about $30 \mu \mathrm{g} / \mathrm{L}$ (well $\mathrm{YD}-58-50-218$ ). The average concentrations of dissolved zinc ranged from about $10 \mu \mathrm{g} / \mathrm{L}$ (well $\mathrm{YD}-58-50-220$ ) to about $400 \mu \mathrm{g} / \mathrm{L}$ (well YD-58-42-926). The maximum concentrations of dissolved copper $(110 \mu \mathrm{g} / \mathrm{L})$ and dissolved lead $(40 \mu \mathrm{g} / \mathrm{L})$ were detected in samples from well $\mathrm{YD}-58-50-18$, which is located in the predominantly urban and rural drainage area of Barton Creek. The maximum concentration of dissolved zinc $(470 \mu \mathrm{g} / \mathrm{L})$ was detected in a sample collected from well YD-58-42-926, which is located in the predominantly residential drainage area of Dry Creek. The galvanized-iron casing and the pump are possible sources of zinc in samples from well YD-58-42-926. However, samples from test well YD-58-50-218, which has a PVC casing and no pump, contained from 100 to $260 \mu \mathrm{g} / \mathrm{L}$ of dissolved zinc. Concentrations of dissolved copper, dissolved lead, and dissolved zinc in samples collected from Barton Springs 
during storm runoff in April and May were significantly less than concentrations in samples from either well YD-58-50-218 or YD-58-42-926. This relation indicates that concentrations of these elements in recharge water to the Edwards aquifer during storm runoff were either diluted by ground water with smaller concentrations or were removed by processes such as oxidation, chemical precipitation, and adsorption as the water circulated through the aquifer.

\section{SUMMARY OF CONCLUSIONS}

Recharge to the Edwards aquifer in the Austin area occurs primarily by infiltration of surface water from streams that cross the Balcones fault zone. About 85 percent of the total recharge occurs along the main channels of six streams in the recharge zone. The daily-mean recharge during the 1982 water year (October 1, 1981, to September 30, 1982) ranged from about $4 \mathrm{ft} 3 / \mathrm{s}$ during the predominantly dry weather in August and September to about $340 \mathrm{ft} 3 / \mathrm{s}$ after a storm in May. The mean recharge for the 1982 water year was $51 \mathrm{ft} / \mathrm{s}$.

Discharge from the Edwards aquifer in the Austin area during the 1982 water year averaged about $70 \mathrm{ft} 3 / \mathrm{s}$. The major point of discharge was Barton Springs, which is the source of water for a municipal swimming pool and for part of the inflow to Town Lake, a water-supply reservoir for the city of Austin. The daily-mean discharge for Barton Springs during the 1982 water year averaged about $59 \mathrm{ft} 3 / \mathrm{s}$ and ranged from $34 \mathrm{ft} / \mathrm{s}$ after dry weather in September 1982 to $91 \mathrm{ft}^{3} / \mathrm{s}$ after storm runoff in October 1981 .

Networks of steeply dipping faults and joints, large caverns, and underground channels afford the rapid movement of water through the aquifer. The direction of the ground-water movement generally is to the east-northeast in the northern part of the aquifer and to the east in the southern part of the aquifer. These avenues for rapid movement of ground water make the recharge zone of the Edwards aquifer in the Austin area particularly susceptible to pollution from natural and human sources during storm runoff.

On the basis of the analyses of samples collected weekly from Barton Springs and of samples collected periodically from Barton Springs and five selected wells during storm runoff, ground water in the recharge zone of the Edwards aquifer in the Austin area is very hard and of the calcium bicarbonate type. The concentrations of dissolved major and minor elements (including dissolved solids, chloride, sulfate, arsenic, barium, cadmium, chromium, copper, iron, lead, manganese, mercury, selenium, silver, and zinc) and total nitrate nitrogen were less than the primary maximum contaminant levels or secondary maximum contaminant levels set for public water systems by the U.S. Environmental Protection Agency $(1976,1977 \mathrm{~b})$. The concentrations of some of these and other elements and bacterial densities in the ground water varied temporally. Statistical analyses of water-quality data for Barton Springs verified at the 90- or 95-percent-confidence level that the densities of fecal coliform and fecal streptococcal bacteria, specific conductance, and concentration of total nitrate nitrogen varied significantly in response to changes in the quantity of recharge to the aquifer.

Densities of fecal coliform bacteria in samples collected from Barton Springs ranged from less than 1 col/100 $\mathrm{mL}$ during dry weather in November 1981 and January and August 1982 to $6,100 \mathrm{col} / 100 \mathrm{~mL}$ during a storm in May 1982. 
Densities of fecal streptococcal bacteria ranged from 1 col/100 mL during dry weather in December 1981 to $11,000 \mathrm{col} / 100 \mathrm{~mL}$ during a storm in May 1982 . During each of three significant storms in October 1981 and April and May 1982, the densities of both groups of bacteria exceeded $1,000 \mathrm{col} / 100 \mathrm{~mL}$, and the ratio of fecal coliform bacteria to fecal streptococcal bacteria in most samples was less than 0.7 . This relation generally indicates that the principal source of fecal pollution in recharge resulting from significant storms and moving rapidly through the aquifer were wastes from domestic and wild animals rather than from humans.

Specific-conductance values of samples from Barton Springs ranged from 438 umhos after a storm in October 1981 to 682 umhos after a relatively long period of deficient precipitation in September 1982. The specific conductance and thus the mineralization of the ground water generally were inversely related to the quantity of recharge. During periods of significant precipitation on the drainage area, recharge was less mineralized than water in the aquifer. As the less mineralized recharge moved through the aquifer, it diluted the concentrations of the major inorganic ions in the water.

Total nitrate nitrogen was the most prevalent form of nitrogen in samples from Barton Springs. Concentrations of nitrate nitrogen ranged from $0.51 \mathrm{mg} / \mathrm{L}$ after a storm in October 1981 to $1.6 \mathrm{mg} / \mathrm{L}$ after dry weather in February and September 1982. During significant precipitation on the drainage area, recharge contained less nitrate nitrogen than water in the aquifer. As this recharge moved through the aquifer, it diluted the concentrations of nitrate nitrogen in the aquifer.

The concentrations of total organic nitrogen, total ammonia nitrogen, total nitrite nitrogen, total phosphorus, and TOC varied erratically in samples collected from Barton Springs during dry weather and during storm runoff. Analyses of water-quality data collected periodically from the streamflow station on Barton Creek at Loop 360 show that the concentrations of these constituents in storm runoff were directly related to the concentrations of suspended solids. The concentrations of the chemical constituents were significantly greater in storm runoff than in the ground water discharged Barton Springs. This relation indicates that concentrations of these chencal constituents in the sediment-laden recharge from storm runoff were decreised by processes such as sedimentation, chemical precipitation, and adsorption as the recharge moved through the aquifer. 


\section{SELECTED REFERENCES}

American Public Health Association and others, 1975, Standard methods for the examination of water and wastewater (14th ed.): Washington, D.C., American Public Health Association, 1193 p.

Ashworth, J. B., 1983, Ground-water availability of the Lower Cretaceous formations in the Hill Country of south-central Texas: Texas Department of Water Resources Report 273, $172 \mathrm{p}$.

Brune, Gunnar, 1981, Springs of Texas, volume 1: Fort Worth, Branch-Smith, Inc., 566 p.

Brune, Gunnar, and Duffin, G. L., 1983, Occurrence, availability, and quality of ground water in Travis County, Texas: Texas Department of Water Resources Report 276, 219 p.

Crawford, C. G., Slack, J. R., and Hirsch, R. M., 1983, Non-parametric test for trends in water-quality data using the Statistical Analysis System: U.S. Geological Survey Open-File Report, 83-550, 102 p.

Geldriech, E. E., and Kenner, B. A., 1969, Concepts of fecal streptococci in stream pollution: Federal Water Pollution Control Association Journal, v. 41 , p. 336-352.

W. F. Guyton and Associates, 1964, Barton Springs and associated ground-water conditions, with particular reference to possible effects of a proposed sewer line in the Barton Creek area: Austin, report to the City of Austin, $17 \mathrm{p}$.

Hem, J. D., 1970, Study and interpretation of the chemical characteristics of natural water (2d ed.): U.S. Geological Survey Water-Supply Paper 1473, $363 \mathrm{p}$.

Mckee, J. E., and Wolf, H. W., 1963, Water quality criteria (2d ed.): California State Water Quality Board Publication No. 3-A, 548 p.

National Academy of Sciences, National Academy of Engineering, 1973 [1974], Water quality criteria, 1972: Washington, D.C., Report of the Committee on Water Quality Criteria, 594 p.

National Technical Advisory Committee to the Secretary of the Interior, 1968, Water quality criteria: Washington, D.C., U.S. Government Printing office, $234 \mathrm{p}$.

St. Clair, E. A., 1979, Quality of water in the Edwards aquifer, central Travis County, Texas: University of Texas at Austin, unpublished M.S. thesis, $95 \mathrm{p}$.

Senger, Rainer, 1983, Hydrogeology of Barton Springs, Austin, Texas: University of Texas at Austin, unpublished M.S. thesis, $120 \mathrm{p}$.

Slade, R. M., Jr., Dorsey, M. E., Gordon, J. D., and Mitchell, R. N., 1980, Hydrologic data for urban studies in the Austin, Texas, metropolitan area, 1978: U.S. Geological Survey Open-File Report 80-728, 229 p.

Slade, R. M., Jr., Dorsey, M. E., Gordon, J. D., Mitchell, R. N., and Gaylord, J. L., 1981, Hydrologic data for urban studies in the Austin, Texas, metropolitan area, 1979: U.S. Geological Survey Open-File Report 81-628, 281 p.

Slade, R. M., Jr., Gaylord, J. L., Dorsey, M. E., Mitchell, R. N., and Gordon, J. D., 1982, Hydrologic data for urban studies in the Austin, Texas, metropolitan area, 1980: U.S. Geological Survey Open-File Report 82-506, 264 p.

Slade, R. M., Jr., Veenhuis, J. E., Dorsey, M. E., Gardiner, Heather, and Smith, A. E., 1983, Hydrologic data for urban studies in the Austin, Texas, metropolitan area, 1981: U.S. Geological Survey Open-File Report 83-44, 293 p.

U.S. Environmental Protection Agency, 1976, National interim primary drinking water regulations: Office of Water Supply, EPA-570/9-76-003, 159 p. 
1977a, Quality criteria for water, 1976: U.S. Government Printing Office, $256 \mathrm{p}$.

1977b, National secondary drinking water regulations: Federal Register, v. 42 , no. 62, pt. I, p. $17143-17147$.

Winslow, A. G., and Kister, L. R., Jr., 1956, Saline water resources of Texas: U.S. Geological Survey Water-Supply Paper 1365, 105 p. 
SUPPLEMENTAL IMFORI:ATION

$-34-$ 


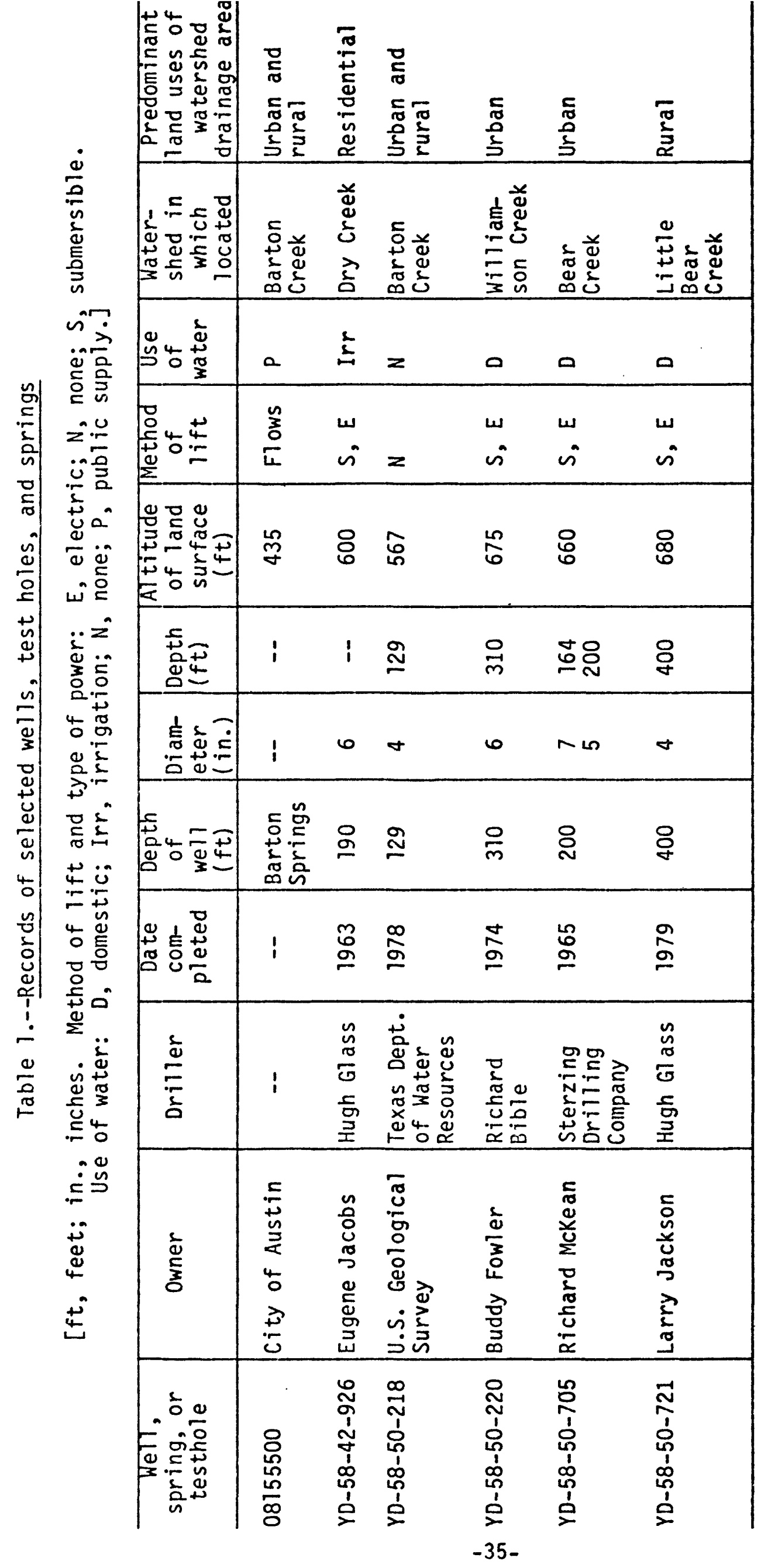


Table 2.--Source and significance of selected constituents and properties comononly reported in water analyses 1/

(mg/L, milligrams per liter; $\mu \mathrm{g} / \mathrm{L}$, micrograms per liter; micromhos, micromhos per centimeter at $25^{\circ} \mathrm{Cel} \mathrm{sius}$ )

Constituent

or property

Silica

$\left(\mathrm{SiO}_{2}\right)$

Silicon ranks second only to oxygen in abundance in the Earth's crust. Contact of natural waters with silica-bearing rocks and soils usually results in a concentration range of about 1 to 30 $\mathrm{mg} / \mathrm{L}$; but concentrations as 1 arge as $100 \mathrm{mg} / \mathrm{L}$ are common in waters in some areas.

Iron

(Fe)

Calcium

(Ca)

Iron is an abundant and widespread constituent of many rocks and soils. Iron concentrations in natural waters are dependent upon several chemical equil ibria processes including oxidation and reduction; precipitation and solution of hydroxides, carbonates, and sulfides; complex formation especially with organic material; and the metabolism of plants and animals. Dissolved-iron concentrations in oxygenated surface waters seldom are as much as $1 \mathrm{mg} / \mathrm{L}$. Some ground waters, uncxygenated surface waters such as deep waters of stratified lakes and reservoirs, and acidic waters resulting from discharge of industrial wastes or drainage from mines may contain considerably more iron. Corrosion of iron casings, pumps, and pipes may add iron to water pumped from wells.

Calcium is widely distributed in the common minerals of rocks and soils and is the principal cation in meny natural freshwaters, especially trose that contact deposits or soils originating from I imestone, dolomite, gypsum, and gypsiferous shale. Calcium concentrations in freshwaters usualiy range from zero to several hundred milligrams per liter. Larger concentrations are not uncommon in waters in arid regions, especially in areas where some of the more sol uble rock types are present.

Magnesium (Mg)

Magnesium ranks eight among the el ements in order of abundance in the Earth's crust and is a common constituent in natural water. Ferromagnesian minerals in igneous rock and magnesium carbonate in carbonate rocks are two of the more important sources of magnesium in natural waters. Magnesium concentrations in freshwaters usually range from zero to several hundred milligrams per liter; but larger concentrations are not uncommon in waters associated with limestone or dolomite.

\section{Sodi um}

(Na)
Sodium is an abundant and widespread constituent of many soils and rocks and is the principal cation in many natural waters associated with argillaceous sediments, marine shales, and evaporites and in sea water. Sodium salts are very soluble and once in solution tend to stay in solution. Sodium concentrations in natural waters vary from less than $1 \mathrm{mg} / \mathrm{L}$ in stream runoff from areas of high rainfall to more than $100,000 \mathrm{mg} / \mathrm{L}$ in ground and surface waters associated with halite deposits in arid areas. In addition to natural sources of sodium, sewage, industrial effluents, oilfield brines, and deicing salts may contribute sodium to surface and ground waters.

\author{
Significance
}

Al though silica in some domestic and industrial water supplies may inhibit corrosion of iron pipes by forming protective coatings, it generally is objectionable in industrial supplies, particularly in boiler feedwater, because it may form hard scale in boilers and pipes or deposit in the tubes of heaters and on steamturbine blades.

Iron is an objectionable constituent in water supplies for domestic use because it may adversely affect the taste of water and beverages and stain laundered clothes and plumbing fixtures. According to the National Secondary Drinking Water Regulations proposed by the U.S. Environmental Protection Agency (1977b), the secondary maximum contamination level of iron for public water systems is $300 \mu \mathrm{g} / \mathrm{L}$. Iron al so is undesirable in some industrial water supplies, particularly in waters used in highpressure boilers and those used for food processing, production of paper and chemicals, and bleaching or dyeing of textiles.

Calcium contributes to the total hardness of sater. Small concentrations of calcium cartonate combat corrosion of metall ic pipes by forming protective coatings. Calcium in domestic water supplies is objectionable because it tends to cause incrustations on cooking utensils and water heaters and increases soap or detergent consumption in waters used for washing, bathing, and 1 aundering. Calcium al so is undesirable in some industrial water suppl ies, particularly in waters used by el ectroplating, textile, pulp and paper, and brewing industries and in water used in high-pressure boilers.

Magnesium contributes to the total haraness of water. Large concentrations of magnesium are objectionable in domestic water supplies because they can exert a cathartic and diuretic action upon unacclimated users and increase soap or detergent consumption in waters used for washing, bathing, and laundering. Magnesium al so is undesirable in some industrial supplies, particularly in waters used by textile, pulp and paper, and brewing industries and in water used in high-pressure boilers.

Sodium in drinking water may impart a salty taste and may be harmful to persons suffering from cardiac, renal, and circulatory diseases and to women with toxemias of pregnancy. Sodium is objectionable in boiler feedwaters because it may cause foaming. Large sodium concentrations are toxic to most plants; and a large ratio of sodium to total cations in irrigation waters may decrease the permeability of the soil, increase the $\mathrm{pH}$ of the soil solution, and impair drainage. 
Table 2.--Source and significance of selected constituents and properties commonly reported in water analyses--Cont inued

Constituent or property

Potassium (K)

\section{Alkalinity}

Sul fate

$\left(\mathrm{SO}_{4}\right)$

Chloride

(CI)

Fluoride (F)

Source or cause

Significance

Although potassium is only slightly less common than sodium in igneous rocks and is more abundant in sedimentary rocks, the concentration of potassium in most natural waters is much smaller than the concentration of sodium. Potassium is liberated from silicate minerals with greater difficulty than sodium and is more easily adsorbed by clay minerals and reincorporated into sol id weathering products. Concentrations of potassium more than $20 \mathrm{mg} / \mathrm{L}$ are unusual in natural freshwaters, but much larger concentrations are not uncommon in brines or in water from hot springs.

Alkal inity is a measure of the capacity of a water to neutralize a strong acid, usually to $\mathrm{pH}$ of 4.5, and is expressed in terms of an equivalent concentration of calcium carbonate $\left(\mathrm{CaCO}_{3}\right)$. Alkal inity in natural waters usually is caused by the presence ob bicarbonate and carbonate ions and to a lesser extent by hydroxide and minor acid radicals such as borates, phosphates, and silicates. Carbonates and bicarbonates are common to most natural waters because of the abundance of carbon dioxide and carbonate minerals in nature. Direct contribution to alkalinity in natural waters by hydroxide is rare and usually can be attributed to contamination. The alkal inity of natural waters varies widely but rarely exceeds 400 to $500 \mathrm{mg} / \mathrm{L}$ as $\mathrm{CaCO}_{3}$.

Sulfur is a minor constituent of the Earth's crust but is widely distributed as metall ic sulfides in igneous and sedimentary rocks. Weathering of metall ic sulfides such as pyrite by oxygenated water yields sul fate ions to the water. Sulfate is dissoived al so from soils and evaporite sediments containing gypsum or anhydrite. The sulfate concentration in natural freshwaters may range from zero to several thousand milligrams per liter. Drainage from mines may add sulfate to waters by virtue of pyrite oxidation.

Chloride is relatively scarce in the Earth's crust but is the predominant anion in sea water, most petroleum-associated brines, and in many natural freshwaters, particularly those associated with marine shales and evaporites. Chloride salts are very soluble and once in solution tend to stay in solution. Chloride concentrations in natural waters vary from less than 1 $\mathrm{mg} / \mathrm{L}$ in stream runoff from humid areas to more than $100,000 \mathrm{mg} / \mathrm{L}$ in ground and surface waters associated with evaporites in arid areas. The discharge of human, animal, or industrial wastes and irrigation return flows may add significant quantities of chloride to surface and ground waters.

Fivoride is a minor constituent of the Earth's crust. The calcium fluoride mineral fluorite is a widespread constituent of resistate sediments and igneous rocks, but its solubility in water is negligible. Fluoride commonly is associated with volcanic gases, and volcanic emanations may be important sources of fluoride in some areas. The
Large concentrations of potassium in drinking water may impart a salty taste and act as a cathartic, but the range of potassium concentrations in most domestic supplies seldom cause these problems. Potassium is objectionable in boiler feedwaters because it may cause foaming. In irrigation water, potassium and sodium act similarly upon the soil, al though potassium generally is considered less harmful than sodium.

Alkaline waters may have a distinctive unpleas ant taste. Alkal inity is detrimental in several industrial processes, especially those involving the production of food and carbonated or acid-fruit beverages. The alkal inity in irrigation waters in excess of alkal ine earth concentrations may increase the $\mathrm{pH}$ of the soil solution, leach organic material and decrease permeability of the soil, and impair plant growth.

Sulfate in drinking water may impart a bitter taste and act as a laxative on unacclimated users. According to the National Secondary Drinking Water Regulations proposed by the Environmental Protection Agency (1977b) the secondary maximum contaminant level of sulfate for public water systems is $250 \mathrm{mg} / \mathrm{L}$. Sulfate al so is undesirable in some industrial supplies, particularly in waters used for the production of concrete, ice, sugar, and carbonated beverages and in waters used in high-pressure boilers.

Chloride may impart a salty taste to drinking water and may accelerate the corrosion of metals used in water-supply systems. According to the National Secondary Drinking Water Reguations proposed by the Environmental Protection Agency (1977b), the secondary maximum contaminant level of chloride for public water systems is $250 \mathrm{mg} / \mathrm{L}$. Chloride al so is objectionable in some industrial supplies, particularly those used for brewing and food processing, paper and steel production, and textile processing. Chloride in irrigation waters generally is not toxic to most crops but may be injurious to citrus and stone fruits.

Fluoride in drinking water decreases the incidence of tooth decay when the water is consumed during the period of enamel calcification. Excessive quantities in drinking water consumed by children during the period of enamel calcification may cause a characteristic discoloration (mottling) of the teeth. According to the 
Table 2.--Source and significance of selected constituents and properties commonly reported in water analyses--Continued

Constituent

or property

Fluoride--

Cont.

fluoride concentration in fresh surface waters usually is less than $1 \mathrm{mg} / \mathrm{L}$; but larger concentrations are not uncommon in sal ine water from oil wells, ground water from a wide variety of geologic terranes, and water from areas affected by volcanism.

Nitrogen

(N)

A considerable part of the total nitrogen of the Earth is present as nitrogen gas in the atmosphere. Small amounts of nitrogen are present in rocks, but the element is concentrated to a greater extent in soils or biological material. Nitrogen is a cyclic element and may occur in water in several forms. The forms of greatest interest in water in order of increasing oxidation state, include organic nitrogen, ammonia nitrogen $\left(\mathrm{NH}_{4}-\mathrm{N}\right)$, nitrite nitrogen $\left(\mathrm{NO}_{2}-\mathrm{N}\right)$ and nitrate nitrogen $\left(\mathrm{NO}_{3}-\mathrm{N}\right)$. These forms of nitrogen in water may be derived naturally from the leaching of rocks, soils, and decaying vegetation; from rainfall; or from biochemical conversion of one form to another. Other important sources of nitrogen in water include effluent from wastewater treatment plants, septic tanks, and cesspools and drainage from barnyards, feed lots, and fertilized fields. Nitrate is the most stable form of nitrocen in an oxidizing environment and is usualiy the dominant form of nitrogen in natural waters and in poliuted waters that have undergone self-purification or aerobic treatment processes. Significant quantities of reduced nitrogen often are present in sone ground waters, deep unoxygenated waters of stratified lakes and reservoirs, and waters containing partially stabilized sewage or animal wastes.

Dissolved solids
Theoretically, dissolved solids are anhydrous residues of the dissolved substance in water. In reality, the term "dissolved solids" is defined by the method used in the determination. In most waters, the dissolved solids consist predominantly of silica, calcium, magnesium, sodium, potassium, carborate, bicarboriate, chloride, and sulfate with minor or trace amounts of other inorganic and orgaric constituents. In regions of high rainfall and relatively insoluble rocks, waters may contain dissolved-solids concentrations of less than $25 \mathrm{mg} / \mathrm{L}$; but saturated sodium chloride brines in other areas may contain more than $300,000 \mathrm{mg} / \mathrm{L}$.
Significance

National Interim Primary Drinking Water Regulations established by the Environiental Protection Agency (1976) the maximum contaminant level of fluoride in drinking water varies from 1.4 to $2.4 \mathrm{mg} / \mathrm{L}$, depending upon the annual average of the maximum daily air temperature for the area in which the water system is located. Excessive fluoride is also objectionable in water supplies for some industries, particularly in the production of food, beverages, and pharmaceutical iterns.

Concentrations of any of the forms of nitrogen in water significantly greater than the local average may suggest pollution. liitrate and nitrite are objectionable in drinking water because of the potential risk to bottle-fed infants for methemoglobinemia, a sometimes fatal illness related to the impaiment of the oxygen-carrying ability of the blood. According to the National Interim Prinary Drinking Water Regulations (U.S. Envirominental Protection Agency, 1976), the maximum contaminant level of nitrate (as $\mathrm{N}$ ) in drinking water is 10 $\mathrm{mg} / \mathrm{L}$. Althcugh a maximum contaminant level for nitrite is not specified in the drinking water regulations, Appendix $A$ to the regulations (U.S. Environmental Protection Agency, 1076) indicates that waters with nitrite concentrations (as $\mathrm{N}$ ) greater than $1 \mathrm{mg} / \mathrm{L}$ should not be used for infant feeding. Excessive nitrate and nitrite concentrations are also objectionable in water supplies for some industries, particularly in waters used for the dyeing of wool and silk fabrics and for brewing.

Dissolved-solids values are used widely in evaluating water quality and in comparing waters. The following classification based on the concentratrations of dissolved solids commonly is used by the Geological Survey (Hirislow and Kister, 1956).

$\begin{array}{lr}\text { Classification } & \begin{array}{r}\text { Dissolved-solids } \\ \text { concentration (mg/L) }\end{array} \\ \text { Fresh } & 1,000-3,000 \\ \text { Slightly saline } & 3,000-10,000 \\ \text { Moderately saline } & 10,000-35,000 \\ \text { Very saline } & >35,000\end{array}$

The National Secondary Drinking Water Regulations (U.S. Environmental Protection Agency, 1977b) set a dissolved-solids concentration of 500 $\mathrm{mg} / \mathrm{L}$ as the secondary maximum contaminant level for public water systems. This level was set primarily on the basis of taste thresholds and potential physiological effects, particularly the laxative effect on unacclimated users. Al though drinking waters containing more than $500 \mathrm{mg} / \mathrm{L}$ are undesirable, such waters are used in many areas where less nineralized supplies are not available without any obvious ill effects. Dissolved solids in industrial water 
Table 2.--Source and significance of selected constituents and properties commonly reported in water analyses--Cont inued

Dissolved

solids--

Cont.

Specific conductance

Hardness as $\mathrm{CaCO}_{3}$
Specific conductance is a measure of the ability of water to transmit an electrical current and depends on the concentrations of ionized constituents dissolved in the water. Many natural waters in contact only with granite, well-leached soil, or other sparingly soluble material have a conductance of less than 50 micromhos. The specific conductance of some brines exceed several hundred thousand micromhos.

Hardness of water is attributable to all polyvalent metals but principally to calcium and magnesium ions expressed as $\mathrm{CaCO}_{3}$ (calcium carbonate). Water hardness results naturally from the solution of calcium and magnesium, both of which are widely distributed in common minerals of rocks and soils. Hardness of waters in contact with 1 imestone commonly exceeds $200 \mathrm{mg} / \mathrm{L}$. In waters from gypsiferous formations, a hardness of $1,000 \mathrm{mg} / \mathrm{L}$ is not uncommon.
The $\mathrm{pH}$ of a solution is a measure of its hydrogen ion activity. By definition, the $\mathrm{pH}$ of pure water at a temperature of $25^{\circ} \mathrm{C}$ is 7.00 . Natural waters contain dissolved gases and minerals, and the $\mathrm{pH}$ may deviate significantly from that of pure water. Rainwater not affected significantly by atmospheric pollution generally has a $\mathrm{pH}$ of 5.6 due to the solution of carbon dioxide from the atmosphare. The $\mathrm{pH}$ range of most natural surface and ground waters is about 6.0 to 8.5. Many natural waters are slightly basic ( $\mathrm{pH}$ >7.0) because of the prevalence of carbonates and bicarbonates, which tend to increase the $\mathrm{pH}$. supplies can cause foaming in boilers; interfere with clearness, color, or taste of many finished products; and accelerate corrosion. Uses of water for irrigation al so are limited by excessive dissolved-solids concentrations. Dissolved solids in irrigation water may adversely affect plants directly by the devel opment of high osmotic conditions in the soil solution and the presence of phytoxins in the water or indirectly by their effect on soils.

The specific conductance is an indication of the degree of mineralization of a water and may be used to estimate the concentration of dissolved solids in the water.

Hardness values are used in evaluating water quality and in comparing waters. The following classification is commonly used by the Geological Survey.

Hardness (mg/L as $\left.\mathrm{CaCO}_{3}\right)$ Classification $0-60$

$61-120$

$121-180$ $>180$

Soft

Moderatel y hard

Hard

Very hard

Excessive hardness of water for domestic use is objectionable because it causes incrustations on cooking utensils and water heaters and increased soap or detergent consumption. Excessive hardness is undesirable al so in many inaustrial supplies. (See discussions concerning calcium and magnesium.)

The $\mathrm{pH}$ of a domestic or industrial water supply is significant because it may affect taste, corrosion potential, and water-treatment processes. Acidic waters may have a sour taste and cause corrosion of metals and concrete. The National Secondary Drinking Water Regulations (U.S. Environmental Protection Agency, 1977b) set a $\mathrm{pH}$ range of 6.5 to 8.5 as the secondary maximum contaminant level for public water systems.

1/ Most of the material in this table has been summarized from several references. For a more thorough discussion of the source and significance of these and other water-quality properties and constituents, the reader is referred to the following additional references: American Public Health Association and others (1975); Hem (1970); McKee and Wolf (1963); National Academy of Sciences, National Academy of Engineering (1973); National Technical Advisory Committee to the Secretary of the Interior (1968); and U.S. Environmental Protection Agency (1977a). 
Table 3.--Summary of regulations for selected water-quality constituents and properties for public water systems

( $\mu g / L$ - micrograms per liter; mg/L - milligrams per liter)

\section{DEFINITIONS}

Contaminant.--Any physical, chemical, biological, or radiological substance or matter in water.

Primary maximum contaminant level.-The maximum permissible level of a contaminant in water which is delivered to the free-flowing outlet of the uitimate user of a public water system. Maximum contaminant levels are those levels set by the U.S. Environmental Protection Agency (1976) in the National Interim Primary Drinking Water Regulations. These regulations deal with contaminants that may have a signicant direct impact on the health of the consumer and are enforceable by the Environmental Protection Agency.

Secondary maximum contaminant level.-The advisable maximum level of a contaminant in water which is delivered to the free-flowing outlet of the ultimate user of a public water system. Secondary maximum contaninant levels are those levels proposed by the Environmental Protection Agency (1977b) in the National Secondary Drinking Water Regulations. These regulations deal with contaminants that may not have a significant direct impact on the health of the consumer, but their presence in excessive quantities may affect the esthetic qualities and discourage the use of a drinking-water supply by the public.

INORGANIC CHEMICALS AND RELATED PROPERTIES

\section{Contaminant}

Arsenic (As)

Barium ( $\mathrm{Ba}$ )

Cadmium ( $C d$ )

Chloride (Cl)

Chromium (Cr)

Copper (Cu)

Iron (Fe)

Lead $(\mathrm{Pb})$

Manganese $(M n)$

Mercury $(\mathrm{Hg})$

Nitrate (as N)

$\mathrm{pH}$

Selenium ( $\mathrm{Se}$ )

Silver $(\mathrm{Ag})$

Sulfate $\left(\mathrm{SO}_{4}\right)$

Zinc $(Z n)$

Dissolved solids
Maximum contaminant level

$50 \mu \mathrm{g} / \mathrm{L}$

$1,000 \mu \mathrm{g} / \mathrm{L}$

$10 \mu \mathrm{g} / \mathrm{L}$

$--$

$50 \mu \mathrm{g} / \mathrm{L}$

$-$

$-$

$50 \mu \mathrm{g} / \mathrm{L}$

$-$

$2 \mu \mathrm{g} / \mathrm{L}$

$10 \mathrm{mg} / 1$

$--$

$10 \mu \mathrm{g} / \mathrm{L}$

$50 \mu g / L$

--

$-$

$-$
Secondary maximum contaminant level

$$
\begin{gathered}
-- \\
-- \\
250 \mathrm{mg} / \mathrm{L} \\
\overline{-} \\
1,000 \mu \mathrm{g} / \mathrm{L} \\
300 \mu \mathrm{g} / \mathrm{L} \\
\overline{50} \mu \mathrm{g} / \mathrm{L} \\
\overline{-} \\
6.5-8.5 \\
-- \\
250 \mathrm{mg} / \mathrm{L} \\
5,000 \mu \mathrm{g} / \mathrm{L} \\
500 \mathrm{mg} / 1
\end{gathered}
$$


Table 4.- - Water-quality data for Barton Springs at Austin (stat Lon 08155500)

(CFS, cubic feet per second; UMIOS, micronhos per centineter at $25^{\circ}$ Celsius; DEG C, degrees Celsius; $\mathrm{MG} / \mathrm{l}$, nllifgrams per liter; COLS./100 ML, colonies per 100 millineters; UG/L, micrograms per liter; $K$, non-ideal colony count)



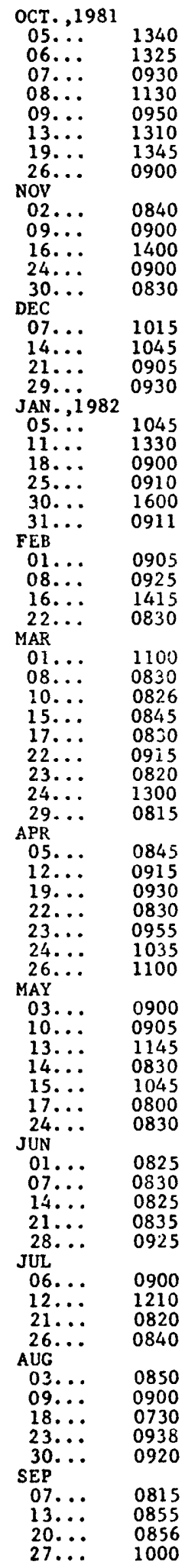

$\begin{array}{llll}81 & 589 & 6.7 & 22.0 \\ 82 & 600 & 7.0 & 22.0 \\ 84 & 574 & 6.9 & 22.0 \\ 86 & 573 & 6.8 & 21.5 \\ 88 & 558 & 6.9 & 21.5 \\ 90 & 438 & 7.6 & 24.5 \\ 87 & 530 & 7.5 & 20.0 \\ 85 & 531 & 7.6 & 16.5\end{array}$

$\begin{array}{rr}7.0 & 81 \\ 6.6 & 77 \\ 6.5 & 76 \\ 6.8 & 78 \\ 6.6 & 77 \\ 8.5 & 102 \\ 9.2 & 100 \\ 9.1 & 96\end{array}$

81
77
76
78
77
102
100
96

$\begin{array}{rr}88 & 45 \\ 53 & K 72 \\ 2100 & 4200 \\ 720 & 2700 \\ 150 & 420 \\ 260 & 180 \\ 33 & 22 \\ 61 & 150 \\ 83 & 540 \\ K 11 & 38 \\ K 8 & K 4 \\ K 1 & 22 \\ <1 & K 2\end{array}$

$78 \quad 585$

564

$7.2 \quad 22.0$

8.5

$\begin{array}{ll}7.0 & 21.0 \\ 7.1 & 20.0\end{array}$

$\begin{array}{ll}7.1 & 20.0 \\ 7.2 & 21.0\end{array}$

7.2

566
588

7.2

21.0

6.5
6.8

98

82
77

$\begin{array}{lll}585 & 7.1 & 21.0 \\ 590 & 7.2 & 21.0 \\ 583 & 7.1 & 21.0\end{array}$

7.0

7.0
6.4
6.4

7.120 .0

6.6

$\mathrm{K} 6$
$\mathrm{~K} 2$
$\mathrm{~K} 3$

K3

583

$\begin{array}{llll}66 & 588 & 7.2 & 21.0 \\ 62 & 598 & 7.2 & 20.5 \\ 59 & 604 & 7.2 & 21.0 \\ 56 & 602 & 7.2 & 21.0\end{array}$

5.3

$7.2 \quad 21.0$

6.2

591
586

7.3

7.3

6.2

21.0

6.2

34

K1

$56 \quad 577$

$\begin{array}{lll}577 & -- & 14.0 \\ 604 & 7.2 & 20.5\end{array}$

$\begin{array}{lll}618 & 7.2 & 20.5\end{array}$

8.8

$\begin{array}{lll}618 & 7.2 & 21.0\end{array}$

6.6
5.6

6.6

$\begin{array}{lll}634 & 7.2 & 21.0 \\ 621 & 7.1 & 21.5\end{array}$

6.4
5.6

$\begin{array}{lll}621 & 7.1 & 21.5 \\ 619 & 6.9 & 21.0\end{array}$

$624 \quad 7.1 \quad 21.0$

-

613
626

626
604

$\begin{array}{rr}7.1 & 21.0 \\ 7.2 & 21.0\end{array}$

$\begin{array}{ll}7.2 & 21.0 \\ 7.2 & 21.0\end{array}$

$7.2 \quad 20.5$

5.6

5.8

5.6
6.2

608

7.2

$\begin{array}{ll}625 & 7 \\ 628 & 7 \\ 638 & 7\end{array}$

$\begin{array}{ll}7.2 & 21.0 \\ 7.2 & 20.5\end{array}$

5.8

80

74
73

K2

$\begin{array}{lll}628 & 7.2 & 21.0 \\ 564 & 7.2 & 21.0\end{array}$

$\begin{array}{lll}628 & 7.2 & 21.0 \\ 564 & 7.2 & 21.0 \\ 577 & 7.2 & 20.5 \\ 589 & 7.1 & 21.0\end{array}$

5.4

5.7

6.8

5.6

6.2
6.4

60
69
77

$\begin{array}{rr}K 1 & K 8 \\ K 9 & K 4 \\ 31 & K 6 \\ K 8 & K 2 \\ 520 & 39\end{array}$

71
70

1400

1300

$\begin{array}{ll}7.2 & 20.5 \\ 7.1 & 21.5 \\ 7.2 & 21.0\end{array}$

584

585
580

6.2
6.4
7.0

$7.2 \quad 21.0$

7.0

$\begin{array}{ll}7.2 & 21.0\end{array}$

7.2

519

560

7.2

86
74
64

$\begin{array}{rr}K 8 & 50 \\ 32 & \mathrm{~K} 4 \\ 4500 & 520 \\ 1100 & 120\end{array}$

270

72

820

23
170

179
130

130
23
520

520
51

$\times 16$

54
$\mathrm{~K} 12$

700

1800
960

230

24
$\mathrm{~K} 6$
$\mathrm{~K} 17$
$\mathrm{~K} 4$
31
23
3200
65

$\begin{array}{lll}565 & 7.2 & 21.5\end{array}$

5.8

$\begin{array}{lll}549 & 7.1 & 22.0 \\ 570 & 7.0 & 22.0\end{array}$

$\begin{array}{lll}575 & 7.2 & 22.0\end{array}$

6.2

6.4

6.7
6.5

48
$\mathrm{~K} 11$

$\mathrm{K} 11$
820
6100

6100
$\times 1700$

$K 1700$
180

K17

$K 7$
130
$K 8$
4800
9600
1900
380

$\begin{array}{lll}585 & 7.1 & 22.0\end{array}$

6.2
6.6

595

$7.3 \quad 22.0$

574
608

7.1

21.5

5.3
6.0

K3

$\mathrm{K} 5$
$\mathrm{~K} 4$
390

$\mathrm{K} 9$
$\times 340$

$\mathrm{K} 10$
$\mathrm{~K} 12$
190
11000
3000
500
25

$47 \quad 638$

$7.0 \quad 20.5$

6.2

$\begin{array}{lll}631 & 7.1 & 22.0\end{array}$

$\begin{array}{lll}648 & 7.1 & 21.5\end{array}$

$\begin{array}{lll}648 & 7.1 & 22.0 \\ 653 & 7.2 & 22.0\end{array}$

6.0

6.3
5.1

6.0

$\begin{array}{lll}662 & 7.1 & 22.0\end{array}$

662

$\begin{array}{ll}7.1 & 22.0 \\ 7.1 & 22.0 \\ 7.1 & 22.0\end{array}$

5.8

674
682

7.1

22.0

5.5
5.4

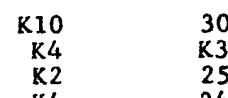

ka

$\begin{array}{lr}<1 & \text { K10 } \\ <1 & \text { K9 }\end{array}$

K

K3
K4

K11

67

$180 \quad \mathrm{~K} 5$

$-41-$ 
Table 4.--Water-quality data for Barton Springs at Austin (station 08155500)--Continued

\begin{tabular}{|c|c|c|c|c|c|c|c|c|}
\hline DATE & $\begin{array}{l}\text { HARD- } \\
\text { NESS } \\
\text { (MG/L } \\
\text { AS } \\
\text { CACO3) }\end{array}$ & $\begin{array}{l}\text { HARD- } \\
\text { NESS, } \\
\text { NONCAR- } \\
\text { BONATE } \\
\text { (MG/L } \\
\text { CACO3) }\end{array}$ & $\begin{array}{l}\text { CALCIUM } \\
\text { OLS- } \\
\text { SOLVED } \\
\text { (MG/L } \\
\text { AS CA) }\end{array}$ & $\begin{array}{l}\text { MAGNE- } \\
\text { SIUM, } \\
\text { DIS- } \\
\text { SOLVED } \\
\text { (MG/L } \\
\text { AS NGG) }\end{array}$ & $\begin{array}{l}\text { SODIUM, } \\
\text { DIS- } \\
\text { SOLVED } \\
\text { (MG/L } \\
\text { AS NA) }\end{array}$ & $\begin{array}{c}\text { SODIUN } \\
\text { AD- } \\
\text { SORP- } \\
\text { TION } \\
\text { RATIO }\end{array}$ & $\begin{array}{l}\text { POTAS- } \\
\text { SIUM, } \\
\text { DIS- } \\
\text { SOLVED } \\
\text { (MG/L } \\
\text { AS K) }\end{array}$ & $\begin{array}{l}\text { ALKA- } \\
\text { LINITY } \\
\text { FIELD } \\
\text { (MG/L } \\
\text { AS } \\
\text { CACO3) }\end{array}$ \\
\hline
\end{tabular}

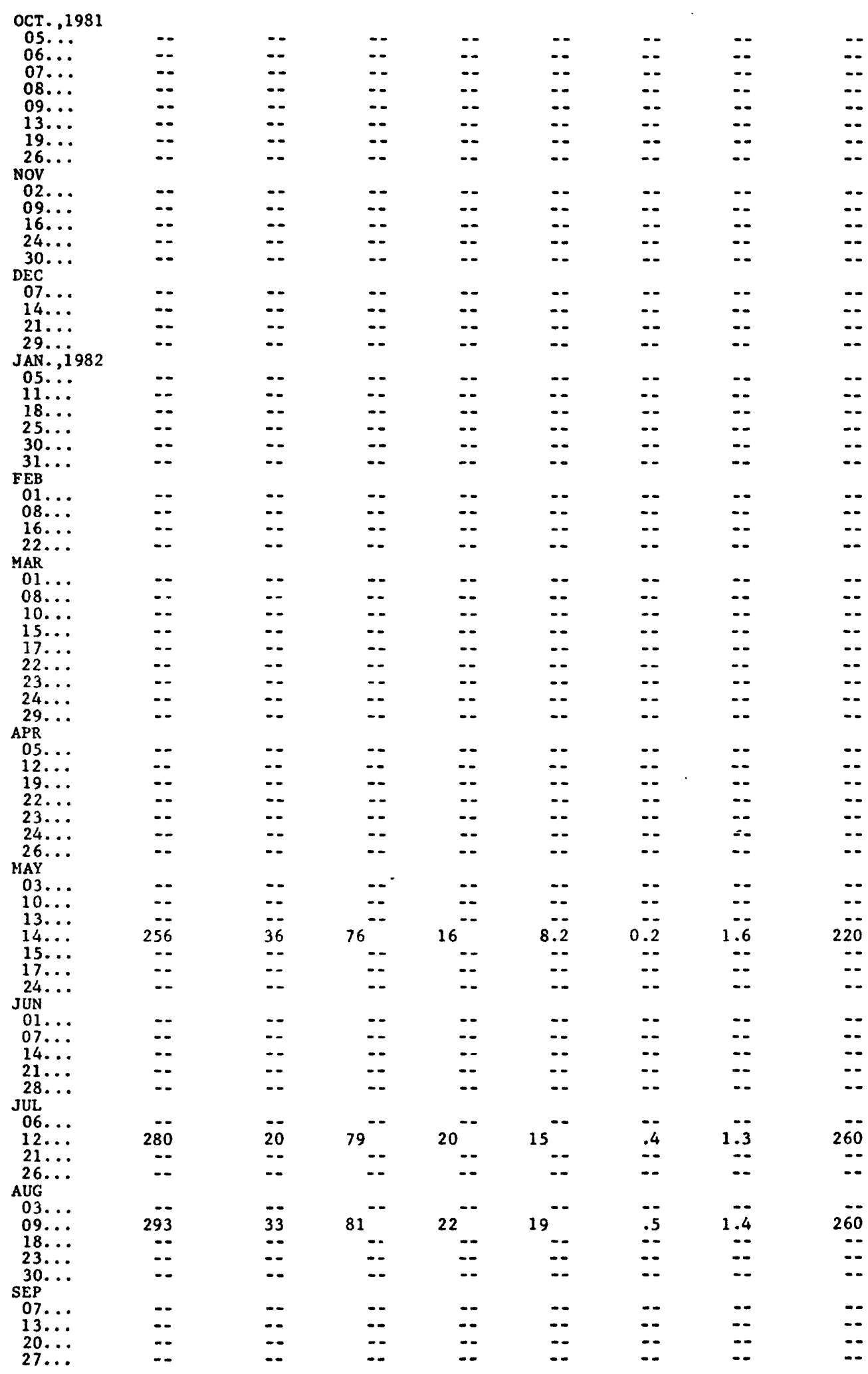




\begin{tabular}{|c|c|c|c|c|c|c|c|c|c|}
\hline $\mathrm{T}$ & $\begin{array}{l}\text { SULFATE } \\
\text { DIS- } \\
\text { SOLVED } \\
\text { (NIG/L } \\
\text { AS SO4) }\end{array}$ & $\begin{array}{l}\text { FLUO- } \\
\text { KIDE, } \\
\text { DIS- } \\
\text { SOLVED } \\
\text { (MG/L } \\
\text { AS F) }\end{array}$ & $\begin{array}{l}\text { CHLO- } \\
\text { RIDL:, } \\
\text { DIS- } \\
\text { SOLVED } \\
\text { (NG/L } \\
\text { AS CL) }\end{array}$ & $\begin{array}{l}\text { SILICA, } \\
\text { DIS- } \\
\text { SOLVED } \\
\text { (MG/L } \\
\text { AS } \\
\text { SIO2) }\end{array}$ & $\begin{array}{l}\text { SOLIDS, } \\
\text { SUM OF } \\
\text { CONSTI - } \\
\text { TUENTS, } \\
\text { DIS- } \\
\text { SOLVED } \\
(\mathrm{MG} / \mathrm{L})\end{array}$ & $\begin{array}{l}\text { SOLIDS, } \\
\text { RESIDUE } \\
\text { AT 105 } \\
\text { DEG. C, } \\
\text { SUS- } \\
\text { PENDED } \\
\text { (MG/L) }\end{array}$ & $\begin{array}{l}\text { NITRO- } \\
\text { GEN, } \\
\text { NITRITE } \\
\text { TOTAL } \\
\text { (MG/L) } \\
\text { AS N) }\end{array}$ & $\begin{array}{c}\text { NITRO- } \\
\text { GEN, } \\
\text { NITRATE } \\
\text { TOTAL } \\
\text { (MG/L) } \\
\text { AS N) }\end{array}$ & $\begin{array}{c}\text { NITRO- } \\
\text { GEN, } \\
\text { N02+NO3 } \\
\text { TOTAL } \\
\text { (NG/L) } \\
\text { AS N) }\end{array}$ \\
\hline
\end{tabular}

OCT. 1981
$05 . .$.

0
0
0
0
0
1
1
2
NO
0
0
1
2
3

$$
\text { } 07 . . .
$$$$
21 . . .
$$$$
\text { JAN. 1982 }
$$

JAN.,1982

11...

$18 \ldots$

$25 \ldots$

$31 \ldots$

FEB

$01 . .$.

$08 . .$.

$16 \ldots$

MAR

$01 . .$.

$08 . .$.

$10 \ldots$

$15 \ldots$

$22 .$.

$23 . .$.

$24 \ldots$

APR

$05 .$.

$12 \ldots$

19...

$23 \ldots$

24 ...

MAY

MAY 03.

$10 \ldots$

$14 \ldots$

$15 .$.

$17 \ldots$

24 JUN

$01 .$.

$07 \ldots$

$14 .$.

$21 \ldots$

28 .

JUL

$06 . .$.

$12 \ldots$

$21 \ldots$

AUG

AUG ...

$09 . .$.

$18 \ldots$

$23 \ldots$

SEP

$07 . .$.

$13 .$.

$20 .$.

$27 \ldots$

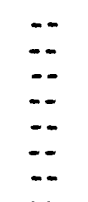

-.

$\because \quad \because \quad \because$

--
$\because-$
$z$

$\because$

$-$

--

$\overline{-}$

$-$

$--$



a-

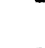

$-$

$\div$

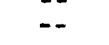

$-$

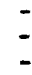

-

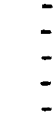

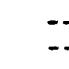

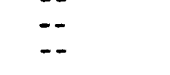


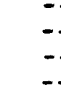

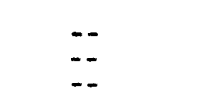

$$
\begin{array}{lll}
2 & -2 \\
- & -2
\end{array}
$$

$$
-
$$$$
\because
$$$$
\text { -. }
$$$$
-
$$$$
\begin{array}{lll}
- & - & - \\
-- & - & - \\
-- & -- & -
\end{array}
$$$$
\overline{--}
$$

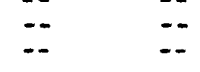$$
\text { -. }
$$$$
\because
$$$$
\because
$$$$
-
$$$$
\begin{array}{lll}
-- & -- & -
\end{array}
$$

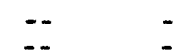$$
\begin{array}{ll}
-- & - \\
-- & - \\
- & -
\end{array}
$$$$
\begin{array}{ll}
-- & - \\
-- & -
\end{array}
$$

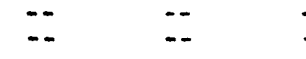$$
\begin{array}{lll}
- & - & \\
\because- & \because & = \\
- & - & =
\end{array}
$$$$
\begin{array}{ll}
-2 & -1 \\
-- & - \\
-- & -
\end{array}
$$$$
22
$$$$
\text { -- }
$$$$
\because \quad \because-8
$$$$
\begin{array}{ll}
- & - \\
\because & = \\
\because- & = \\
-
\end{array}
$$$$
24^{--}
$$$$
25^{-}
$$$$
\begin{array}{lll}
-. & .3 & 30 \\
- & -2
\end{array}
$$$$
\begin{array}{lll}
-- & - \\
-- & -
\end{array}
$$

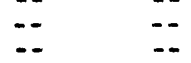$$
\begin{array}{lll}
\because- & \because- & - \\
\because- & \because & \because \\
\because- & \because & -
\end{array}
$$$$
23^{--}
$$$$
\begin{aligned}
& \because: \\
& \because \\
& \because \\
& \because
\end{aligned}
$$$$
\begin{array}{r}
16 \\
19 \\
21 \\
2 \\
2 \\
4 \\
6
\end{array}
$$

16
19
21
2
2
4
6
2

$<0.020$
$<.020$
$<.020$
.020
.020
.030
$<.020$
$<.020$

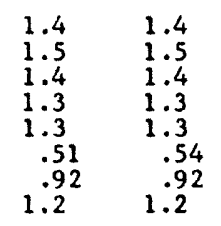

$\because$

0
1
0
0
0

$<.020$
$<.020$
$<.020$
$<.020$

$\begin{array}{ll}1.3 & 1.3 \\ 1.2 & 1.2 \\ 1.2 & 1.2 \\ 1.4 & 1.4\end{array}$

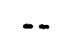

2
13
14

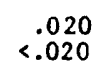

$<.020$

$<.020$

$\begin{array}{ll}1.4 & 1.4 \\ 1.4 & 1.4\end{array}$

$\begin{array}{ll}1.4 & 1.4 \\ 1.4 & 1.4\end{array}$

11
0
0
6
-2

$<.020$
$<.020$
$<.020$

$<.020$

$<.020$

$<.020$

$<.020$
$<.020$

$<.020$

$\begin{array}{ll}1.4 & 1.4\end{array}$

$\begin{array}{ll}1.4 & 1.4 \\ 1.4 & 1.4\end{array}$

$\begin{array}{ll}-\overline{4} & 1.4\end{array}$

$\begin{array}{ll}1.5 & -5 \\ 1.4 & 1.4 \\ 1.5 & 1.6\end{array}$

$<.020$

$<.020$

$<.020$

$<.020$

-.

$<.020$

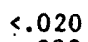

$<.020$

$<.020$

$<.020$

$<.020$

$<.020$
$<.020$

$\begin{array}{ll}1.5 & 1.5\end{array}$

1.31 .3

$1.5 \quad 1.5$

\begin{tabular}{rr}
1.5 & 1.5 \\
\hline 1.5 & 1.5
\end{tabular}

$\begin{array}{ll}1.5 & 1.5\end{array}$

$\begin{array}{ll}1.5 & 1.5 \\ 1.5 & 1.5\end{array}$

$\begin{array}{ll}1.5 & 1.5 \\ 1.4 & 1.4\end{array}$

$\begin{array}{ll}1.4 & 1.4 \\ 1.4 & 1.4\end{array}$

$1.3 \quad 1.3$

$<1$
$<2$
$<2$
31
6
6
$<2$

$<.020$

$<.020$

$<.020$

$<.020$

$<.020$

$<.020$
$<.020$

$\begin{array}{ll}1.1 & 1.0 \\ 1.2 & 1.2\end{array}$

$1.3 \quad 1.3$

$1.0 \quad 1.0$

$\begin{array}{ll}.98 & .98 \\ .87 & .87\end{array}$

3
5
3
$<1$
4

.020

.020
$\square .020$

$<.020$

$<.020$
$<.020$

$\begin{array}{ll}.88 & .90 \\ 1.0 & 1.0 \\ 1.1 & 1.1 \\ 1.2 & 1.2 \\ .96 & .96\end{array}$

$<.020$

$<.020$
$<.020$
$<.020$

$1.2 \quad 1.2$

$11 \stackrel{330}{-.} \quad$

$<2$
$<2$
$<2$
2

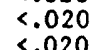

$\begin{array}{ll}1.2 & 1.2 \\ 1.3 & 1.3 \\ 1.4 & 1.4 \\ 1.5 & 1.5\end{array}$

$<.020$

$\begin{array}{rrr}11 & - & 5 \\ -- & 346 & <2 \\ -- & -- & 6 \\ -- & -- & 7\end{array}$

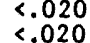

$<.020$
$<.020$

$\begin{array}{lll}<.020 & 1.5 & 1.5 \\ <.020 & 1.5 & 1.5 \\ <.020 & 1.4 & 1.4\end{array}$

$1.5 \quad 1.5$

$\begin{array}{ll}-- & -- \\ -- & =\end{array}$

$<.020$

$<.020$
$<.020$

$\begin{array}{ll}1.6 & 1.6 \\ 1.5 & 1.5 \\ 1.5 & 1.5 \\ 1.6 & 1.6\end{array}$ 
Table 4.--Water-qual1ty data for Barton Springs at Austin (station 08155500)--Continued

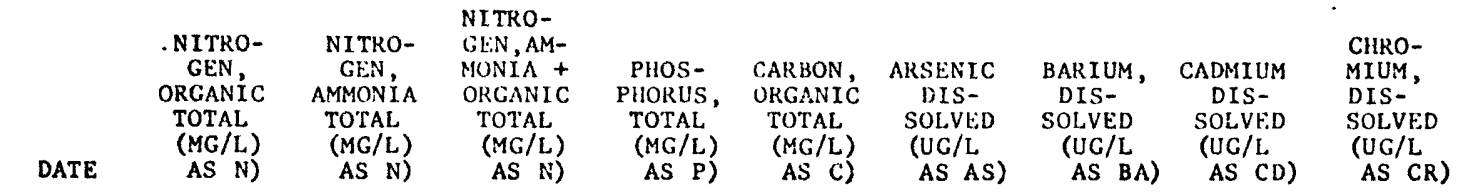

OCT., 1981

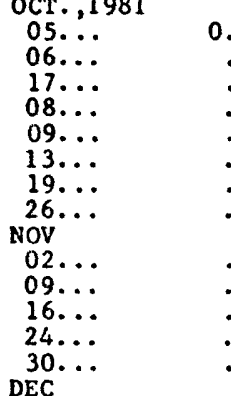

0.61

As

\section{1}

0.010
.010
.010
.010
.010
$<.010$
.070

0.1
.5
.3
.8
.2
2.2
.8
1.3
.1
.4
.6
.5
.7

$\begin{array}{rr}-- & 200 \\ 1 & \\ 1 & 200 \\ 1 & 200 \\ -- & - \\ -- & - \\ -- & - \\ -- & - \\ -- & - \\ -- & -\end{array}$

$\begin{array}{rr}200 & - \\ 0 & < \\ 200 & < \\ 200 & < \\ -- & - \\ -- & - \\ -- & - \\ -- & - \\ -- & - \\ -- & -\end{array}$

$\begin{array}{ll}-- & <- \\ <1 & <10 \\ <1 & <10 \\ <1 & <10 \\ <1 & <10 \\ -- & -- \\ -- & -- \\ -- & - \\ -- & - \\ -- & - \\ -- & -\end{array}$

$07 . \cdots$

$14 \ldots$

$29 . \cdots$

JAN., 198

.16

.81
.51
.53

.110

$<.070$

$<.070$
.070

.27

.81
.51
.60

.2
1.1
1.6

$\because-$

$<.010$

.020
.010
.020

--
--
--

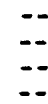

11...

$11 . .$.

$25 \ldots$

$30 .$.

.53

$<.070$

.070
$<.070$

.53

.070
.070

.52

.020

.020
.010
.020

1.0
.6
.9
.1
.6

$<.070$

.27

.010

$<.010$

$01 \ldots$

-070
.060

$<.060$

$<.0$
.020

.020
.010

$22 \ldots$

.22
.89

MAR

$01 \ldots$

$08 .$.

.39

$<.060$

.22

.39

.010

$<.060$
$<.060$

.38

.45

$15 .$.

$17 .$.

$22 \ldots$

$23 .$.

$24 \ldots$

APR

$05 . .$.

$19 .$.

22 ...

$23 .$.

$26 .$.

MAY

$03 . .$.

$13 .$.

$14 \ldots$

$15 .$.

$17 \ldots$

JUN

$01 \ldots$

$14 .$.

$21 \ldots$

JUL

$06 .$.

$12 \ldots$

$26 . .$.

AUG

$03 . .$.

$18 .$.

$30 .$.

SEP

$07 .$.

$13 . .$.

$20 . .$.

.17

.300

.160

--

47

.040
.030

.010

.000

$.060 \quad \overline{77}$

$<.010$

.070
$<.060$

$<.060$
$<.050$

.080

.090
.080

.080
$<.060$

$<.060$

.060

.100
.080

.080
.100

.080

.060

.35
.27
.36

.50

.59
.54
.38

.44
.38

.49
.27

.27

.99
.65
.65

.65

.55
.90

.110

.040
$<.060$

$<.20$

$<.060$
.080

1.00
.80

.80
.80

.010

$<.010$
$<.010$

$<.010$

.010

.020
.010

.010
.100

2.70

.250

$<.010$

.030
.050

.030

.030

$<.060$

.90
2.30

2.30
1.90
1.50

$<.010$

$<.010$

.020

.90

$<.060$

.070

.80
2.00
.80

.72
1.9

.080

.080

.120
$<.060$

.50
1.20

.060
.010
.040

.050

1.2

.180

.70

.070

.070
.070

$<.010$
.020

.010

.020

$<.010$

$<.010$

.40
.50
.70

.080
.060
.030

.43
.63 
Table 4.--Water-qual1ty data for Barton Springs at Austin (station 08155500)--Cont Inued

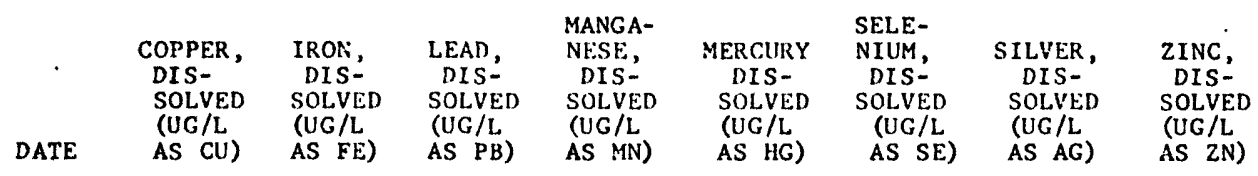

OCT. , 1981

\begin{tabular}{|c|c|c|c|c|c|c|c|c|}
\hline $05 \ldots$ & $=$ & - & - & - & - & -- & -. & -- \\
\hline $\begin{array}{l}06 \ldots \\
07 \ldots\end{array}$ & $\begin{array}{l}1 \\
1\end{array}$ & $\begin{array}{l}60 \\
40\end{array}$ & $\frac{1}{2}$ & $\begin{array}{r}10 \\
<10\end{array}$ & $\begin{array}{r}0.0 \\
.0\end{array}$ & $\begin{array}{l}<1 \\
<1\end{array}$ & $\begin{array}{l}<1 \\
<1\end{array}$ & $\begin{array}{l}10 \\
10\end{array}$ \\
\hline $08 \ldots$ & 1 & 20 & 2 & $<10$ & .0 & $<1$ & $<1$ & 10 \\
\hline & 1 & 30 & 2 & $<10$ & .0 & $<i$ & $<i$ & 10 \\
\hline $13 \ldots$ & $=$ & $\cdots$ & -- & -- & $\cdots$ & -. & $\cdots$ & $\cdots$ \\
\hline $\begin{array}{l}19 . . . \\
26 . .\end{array}$ & $=$ & $=-$ & -- & 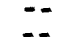 & $\cdots$ & -- & 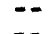 & -. \\
\hline nov & & & & 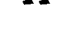 & $\cdots$ & $\cdots$ & $\cdots$ & $=$ \\
\hline $02 \ldots$ & -- & -- & -. & $=$ & -- & -. & -. & $=$ \\
\hline & $\cdots$ & - & $\cdots$ & -- & -- & $\cdots$ & - & 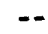 \\
\hline $16 . \cdots$ & $=$ & $=$ & $=$ & -- & - & $\cdots$ & -- & -- \\
\hline $\begin{array}{l}24 \ldots \\
30 \ldots\end{array}$ & $=$ & $\because$ & $\because$ & $\because$ & $\because$ & $\because-$ & $\cdots$ & -- \\
\hline DEC & & & & . & $\cdots$ & $\cdots$ & $-\infty$ & $=$ \\
\hline $07 \ldots$ & -- & -- & -- & -- & $=-$ & -- & -. & -- \\
\hline & -- & -- & $\cdots$ & $-\cdot$ & -- & - & - & -- \\
\hline $21 \ldots$ & $=-$ & $=-$ & - & $=-$ & -- & -- & $=-$ & $\cdots$ \\
\hline JAN.,i982 & $=$ & -- & $\cdots$ & -- & $-\cdot$ & $=$ & $=-$ & $\cdots$ \\
\hline $05 \ldots$ & -. & -- & - & -- & -- & -. & -. & -- \\
\hline $11 \ldots$ & $\cdots$ & $\cdots$ & $\cdots$ & $\cdots$ & $=$ & $\cdots$ & - & - \\
\hline $\begin{array}{l}18 \ldots \\
25 \ldots\end{array}$ & $=$ & $\overline{--}$ & $\because-$ & $=-$ & $\because-$ & $=$ & $\because-$ & $\because-$ \\
\hline $30 . \ldots$ & & & & & $\cdots$ & 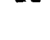 & 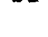 & \\
\hline$\underset{F E B}{31} \ldots$ & $\cdots$ & -- & $\cdots$ & -. & $\cdots$ & $\cdots$ & - & -- \\
\hline $\begin{array}{l}\text { FEB } \\
01 \ldots\end{array}$ & -- & - & -. & - & -- & -. & - & - \\
\hline $08 \ldots$ & -. & - & -- & -- & -. & -- & - & $\because$ \\
\hline $16 \ldots$ & $=$ & -- & $\cdots$ & -- & -. & $=-$ & -- & -. \\
\hline$\underset{M A R}{22} \ldots$ & -- & $\cdots$ & $\cdots$ & $\cdots$ & -- & $-\cdot$ & $=-$ & -- \\
\hline $01 . .$. & - & -- & - & -- & -- & -- & -. & $=-$ \\
\hline $08 \ldots$ & $\cdots$ & $\cdots$ & -- & - & -- & -. & - & $\cdots$ \\
\hline $10 \ldots$ & -- & - & $\because$ & -- & -- & -- & -. & 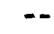 \\
\hline $15 \ldots$ & $\because-$ & $\cdots$ & $\because$ & $\because$ & $=-$ & 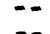 & $=$ & $=-$ \\
\hline $17 \ldots$ & - & $\therefore$ & $\therefore$ & 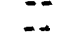 & $\therefore$ & $\because-$ & $=$ & $=-$ \\
\hline $23 \ldots$ & -- & -- & - & - & -- & -- & -- & $=$ \\
\hline $24 \ldots$ & -- & $\cdots$ & -- & -. & -- & -. & -- & - \\
\hline $29 \ldots$ & -- & $=-$ & $\cdots$ & -- & -- & -. & $\cdots$ & -- \\
\hline $\begin{array}{l}\text { APR } \\
05 \ldots\end{array}$ & -. & -. & - & $=-$ & -- & -. & $\ldots$ & $=-$ \\
\hline $12 \ldots$ & -. & -- & -. & $\ldots$ & - & -. & -. &  \\
\hline $19 \ldots$ & -- & 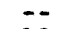 & $\ldots$ & - & $\cdots$ & $=$ & -- & 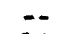 \\
\hline $22 \ldots$ & $<1$ & $<10$ & $<1$ & $<10$ & $<.1$ & 1 & $<1$ & $<10$ \\
\hline $23 \ldots$ & 1 & $<10$ & $<1$ & $<10$ & $<.1$ & 1 & $<1$ & $<10$ \\
\hline $24 \ldots$ & 1 & 30 & $<1$ & $<10$ & $<.1$ & $<1$ & $<1$ & $<10$ \\
\hline MAY 26. & 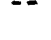 & -- & $\cdots$ & -- & -- & $=$ & $=$ & $=$ \\
\hline $03 \ldots$ & -- & $-\cdot$ & -- & - & - & - & -. & $=-$ \\
\hline $10 \ldots$ & $=$ & 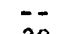 & $\because$ & $=$ & -- & $=-$ & - & $=-$ \\
\hline $13 \ldots$ & 1 & 20 & 3 & $<10$ & $<.1$ & $<1$ & $<1$ & 10 \\
\hline $14 \ldots$ & 2 & 40 & 2 & $<10$ & $<.1$ & $<1$ & $<1$ & 10 \\
\hline $15 \ldots$ & 2 & 40 & $<1$ & $<10$ & $<.1$ & $<1$ & $<1$ & 20 \\
\hline $\begin{array}{l}17 \ldots \\
24 \ldots\end{array}$ & -- & $=$ & -- & -- & $\because$ & -- & $\cdots$ & -- \\
\hline JUN $24 .$. & $\cdots$ & 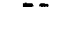 & $\cdots$ & $\cdots$ & 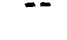 & $\cdots$ & $\cdots$ & -- \\
\hline $01 \ldots$ & -- & -- & - & -. & - & -. & -. &.- \\
\hline $07 \ldots$ & -- & -- & $\cdots$ & -- & $\cdots$ & -- & $\cdots$ & $\cdots$ \\
\hline $14 \ldots$ & $=-$ & 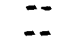 & $\because$ & $\therefore$ & $=$ & $=$ & $=$ & $=$ \\
\hline $28 \ldots$ & - & - & - & - & -- & $\ldots$ & -. & -- \\
\hline JUL & & & & & & & & \\
\hline $06 \ldots$ & -- & 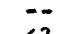 & $\cdots$ & - & $-\overline{-}$ & $\because$ & $=$ & $=$ \\
\hline $12 \ldots$ & 1 & $<3$ & 4 & 2 & $<.1$ & $<1$ & $<1$ & 14 \\
\hline $\begin{array}{l}21 \ldots \ldots \\
26 \ldots\end{array}$ & -- & $=$ & -- & $=-$ & $=$ & -- & -. & $\cdots$ \\
\hline AUG & $\cdots$ & $\cdots$ & $\cdots$ & $\because$ & 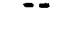 & -- & -- & - \\
\hline $03 \ldots$ & -- & $=-$ & - & $\cdots$ & - & -- & -. & - \\
\hline & $<1$ & $<3$ & $<1$ & $<1$ & $<.1$ & 1 & $<1$ & $<3$ \\
\hline & $\cdots$ & -- & $\cdots$ & $\cdots$ & -- & -- & -- & -- \\
\hline & $\overline{-}$ & 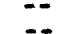 & $\because$ & $\cdots$ & $=$ & $=$ & $=$ & 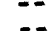 \\
\hline & - & 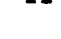 & $\cdots$ & 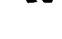 & $\infty$ & $\cdots$ & $\cdots$ &  \\
\hline 07 & -- & - & $\cdots$ & $\cdots$ & $-\infty$ & -- & -. & $\cdots$ \\
\hline & -- & $=-$ & 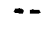 & $\cdots$ & -- & -. & -- & 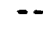 \\
\hline & $=$ & $=-$ & -- & $\cdots$ & -- & -- & -- & -- \\
\hline & & $=-$ & $=$ & $\cdots$ & -- & -- & -- & \\
\hline
\end{tabular}







(CFS, cublc feet per second; UMHOS, micromhos per centimeter at $25^{\circ}$ Celsius; Dig C, degrees Celsius; $\mathrm{MG} / \mathrm{L}$, milifgrams per liter; COLS. $1100 \mathrm{ML}$, colonles per 100 milliliters; UG/L, micrograms per $11 t e r$ )

\begin{tabular}{|c|c|c|c|c|c|c|c|c|c|c|}
\hline DATE & TIME & $\begin{array}{l}\text { STREAM- } \\
\text { FLOW, } \\
\text { INSTAN- } \\
\text { TANEOUS } \\
\text { (CFS) }\end{array}$ & $\begin{array}{l}\text { SPE- } \\
\text { CIFIC } \\
\text { CON- } \\
\text { DUCT- } \\
\text { ANCE } \\
\text { (UMHOS) }\end{array}$ & $\begin{array}{c}\mathrm{PH} \\
\text { (UNITS) }\end{array}$ & $\begin{array}{l}\text { TEMPER- } \\
\text { ATURE } \\
\text { (DEG C) }\end{array}$ & $\begin{array}{l}\text { COLOR } \\
\text { (PLAT- } \\
\text { INUM- } \\
\text { COBALT } \\
\text { UNITS) }\end{array}$ & $\begin{array}{l}\text { TUR- } \\
\text { BID- } \\
\text { ITY } \\
\text { (NTU) }\end{array}$ & $\begin{array}{c}\text { OXYGEN, } \\
\text { DIS- } \\
\text { SOLVED } \\
\text { (MG/L) }\end{array}$ & $\begin{array}{c}\text { OXYGEN, } \\
\text { DIS- } \\
\text { SOLVED } \\
\text { (PER- } \\
\text { CENT } \\
\text { SATUR- } \\
\text { ATION) }\end{array}$ & $\begin{array}{c}\text { OXYGEN } \\
\text { DEMAND, } \\
\text { BIO- } \\
\text { CHEN- } \\
\text { ICAL, } \\
5 \text { DAY } \\
(\mathrm{MG} / \mathrm{L})\end{array}$ \\
\hline $\begin{array}{c}\text { OCT. } 1981 \\
06 . \ldots \ldots \\
06 . \ldots \ldots \\
06 . \ldots \ldots \\
06 . \ldots \ldots \\
06 . \ldots \ldots \\
07 \ldots \\
\text { MAY }, 1982\end{array}$ & $\begin{array}{l}1505 \\
1535 \\
1735 \\
1835 \\
2135 \\
0940\end{array}$ & $\begin{array}{r}256 \\
3050 \\
5240 \\
3920 \\
912 \\
172\end{array}$ & $\begin{array}{l}306 \\
248 \\
166 \\
145 \\
141 \\
228\end{array}$ & $\begin{array}{r}-1 \\
7.7 \\
7 .-9 \\
8.1\end{array}$ & $\begin{array}{c}E \\
-- \\
-- \\
-- \\
23.5\end{array}$ & $\begin{array}{r}20 \\
30 \\
60 \\
120 \\
120 \\
40\end{array}$ & $\begin{array}{r}1100 \\
660 \\
960 \\
900 \\
660 \\
130\end{array}$ & $\begin{array}{l}-- \\
-- \\
-- \\
-- \\
--\end{array}$ & $\begin{array}{l}=- \\
=- \\
=- \\
=-\end{array}$ & $\begin{array}{r}12 \\
5.4 \\
6.7 \\
5.6 \\
5.0 \\
2.1\end{array}$ \\
\hline $\begin{array}{l}13 \ldots \ldots \\
13 \ldots \ldots \\
13 \ldots \ldots \\
14 \ldots \ldots\end{array}$ & $\begin{array}{l}0835 \\
1400 \\
1502 \\
0930\end{array}$ & $\begin{array}{r}410 \\
3360 \\
4160 \\
382\end{array}$ & $\begin{array}{l}233 \\
203 \\
196 \\
366\end{array}$ & $\begin{array}{r}8.0 \\
-. \\
8.0\end{array}$ & $\begin{array}{r}21.0 \\
=- \\
20.0\end{array}$ & $\begin{array}{l}40 \\
60 \\
90 \\
20\end{array}$ & $\begin{array}{r}780 \\
270 \\
440 \\
64\end{array}$ & $\begin{array}{r}8.4 \\
-- \\
8.4\end{array}$ & \begin{tabular}{l}
98 \\
\hdashline- \\
94
\end{tabular} & $\begin{array}{r}2.4 \\
2.6 \\
4.3 \\
.8\end{array}$ \\
\hline
\end{tabular}

\begin{tabular}{|c|c|c|c|c|c|c|c|c|c|c|}
\hline & $\begin{array}{l}\text { COLI- } \\
\text { FORM, } \\
\text { FECAL, } \\
0.7 \\
\text { UM-MF } \\
\text { (COLS./ } \\
100 \mathrm{ML} \text { ) }\end{array}$ & $\begin{array}{l}\text { STREP- } \\
\text { TOCOCCI } \\
\text { FECAL, } \\
\text { KF AGAR } \\
\text { (COLS. } \\
\text { PER } \\
100 \mathrm{ML} \text { ) }\end{array}$ & $\begin{array}{l}\text { HARD- } \\
\text { NESS } \\
\text { (MG/L } \\
\text { AS } \\
\text { CACO3) }\end{array}$ & $\begin{array}{l}\text { HARD- } \\
\text { NESS } \\
\text { NONCAR- } \\
\text { BONATE } \\
\text { (MG/L } \\
\text { CACO3) }\end{array}$ & $\begin{array}{c}\text { CALCIUM } \\
\text { DIS- } \\
\text { SOLVED } \\
\text { (MG/L } \\
\text { AS CA) }\end{array}$ & $\begin{array}{l}\text { MAGNE- } \\
\text { SIUM, } \\
\text { DIS- } \\
\text { SOLVED } \\
\text { (MG/L } \\
\text { AS MG) }\end{array}$ & $\begin{array}{c}\text { SODIUM, } \\
\text { DIS- } \\
\text { SOLVED } \\
\text { (MG/L } \\
\text { AS NA) }\end{array}$ & $\begin{array}{c}\text { SODIUM } \\
\text { AD- } \\
\text { SORP- } \\
\text { TION } \\
\text { RATIO }\end{array}$ & $\begin{array}{c}\text { POTAS- } \\
\text { SIUM, } \\
\text { DIS- } \\
\text { SOLVED } \\
\text { (MG/L } \\
\text { AS K) }\end{array}$ & $\begin{array}{c}\text { ALKA- } \\
\text { LINITY } \\
\text { FIELD } \\
\text { (MG/L } \\
\text { AS } \\
\text { CACO3) }\end{array}$ \\
\hline
\end{tabular}

\begin{tabular}{|c|c|c|c|c|c|c|c|c|c|c|}
\hline \multicolumn{11}{|l|}{ OCT. , 1981} \\
\hline $06 \ldots \ldots$ & 78000 & 86000 & -- & - & -- & -- & $=$ & -- & -- & -- \\
\hline $06 \ldots \ldots$ & $\begin{array}{l}30000 \\
80000\end{array}$ & $\begin{array}{l}21000 \\
38000\end{array}$ & 79 & $-\overline{2}$ & $\overline{24}$ & 4.6 & $\overline{1.8}$ & 0.1 & $2 . \overline{4}$ & $\overline{77}$ \\
\hline $06 \ldots \ldots$ & 70000 & 48000 & $\ldots$ & -- & -- & -- & -- & $\ldots$ & -- & $\cdots$ \\
\hline $06 \ldots \ldots$ & 50000 & 18000 & 70 & 1 & 22 & 3.7 & 1.2 & .1 & 2.5 & 69 \\
\hline MAY,$\ddot{1982}$ & 14000 & 8400 & -- & -- & -- & -- & - & -- & -- & 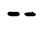 \\
\hline $13 \ldots \ldots$ & 8000 & 12000 & 105 & 15 & 32 & 6.2 & 3.4 & .1 & 1.8 & 90 \\
\hline $13 \ldots \ldots$ & 26000 & 85000 & -- & -- & -- & -- & -- & -- & -- & \\
\hline $13 \ldots \ldots$ & 35000 & 80000 & -- & -- & -- & $\cdots$ & -- & -- & -- & - \\
\hline & 5100 & 4000 & & -- & -- & & -- & $\cdots$ & & \\
\hline
\end{tabular}

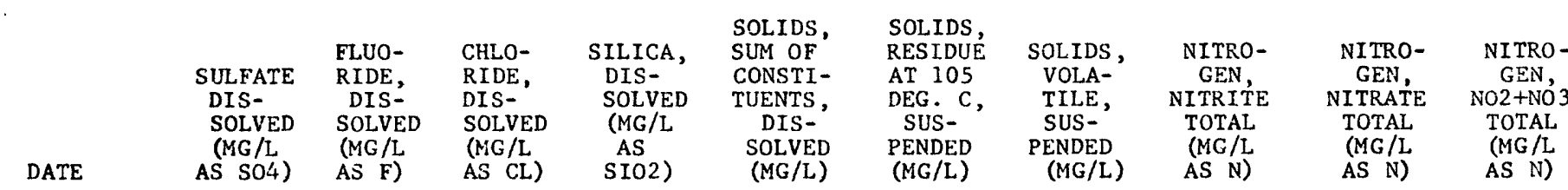

OCT., 1981

\begin{tabular}{|c|c|c|}
\hline $\begin{array}{r}\text { OCT. }, 1981 \\
06 . . \ldots \ldots\end{array}$ & & \\
\hline $06 \ldots \ldots$ & -- & -- \\
\hline $06 \ldots \ldots$ & 5.0 & 0.1 \\
\hline $06 \ldots \ldots$ & - & - \\
\hline $06 \ldots \ldots$ & 5.0 & .1 \\
\hline MAY & 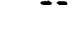 & - \\
\hline $13 \ldots \ldots$ & 15 & .2 \\
\hline $13 \ldots \ldots$ & -- & $\ddot{--}$ \\
\hline $14 \ldots$ & $=$ & - \\
\hline
\end{tabular}

$\begin{array}{rr}-- & -- \\ -- & -\overline{-} \\ 3.5 & 5.8 \\ -\overline{5} & -\overline{-} \\ -- & -- \\ 5.2 & 5.2 \\ -- & -- \\ -- & --\end{array}$

$\begin{array}{rr}-- & 1180 \\ -- & 776 \\ 86 & 1240 \\ -- & 810 \\ 79 & 716 \\ -- & 135 \\ 123 & 1320 \\ -- & 342 \\ -- & 744 \\ -- & 76\end{array}$

136
116
148
125
120
12
151
39
90
25

$$
\begin{array}{r}
0.080 \\
.070 \\
.100 \\
.080 \\
.090 \\
.030 \\
\\
<.020 \\
.040 \\
.030 \\
<.020
\end{array}
$$

$$
\begin{array}{r}
0.20 \\
.12 \\
.09 \\
.11 \\
.10 \\
.20 \\
-. \\
.23 \\
.14
\end{array}
$$$$
\begin{aligned}
& -- \\
& 77 \\
& 69 \\
& -- \\
& 90 \\
& -- \\
& --
\end{aligned}
$$

NITRO-

GEN, AMMONIA + ORGANIC TOTAL (MG/L AS N)
PHOS- CARBON, ARSENIC BARIUM, CADMIUM

\begin{tabular}{|c|c|c|}
\hline $\begin{array}{r}\text { OCT. } 1981 \\
06 . \ldots \ldots \\
06 \ldots \ldots \\
06 . \ldots \ldots \\
06 . \ldots \ldots \\
06 . \ldots \ldots \\
07 \ldots \ldots\end{array}$ & $\begin{array}{l}2.0 \\
1.8 \\
3.3 \\
1.1 \\
1.3 \\
.62\end{array}$ & $\begin{array}{r}0.240 \\
.170 \\
.250 \\
.200 \\
.230 \\
.160\end{array}$ \\
\hline $\begin{array}{r}\text { MAY }, 1982 \\
13 \ldots \ldots \ldots \\
13 \ldots \ldots \\
13 \ldots \ldots \\
14 \ldots \ldots\end{array}$ & $\begin{array}{l}1.2 \\
1.2 \\
2.2 \\
.68\end{array}$ & $\begin{array}{l}.170 \\
.140 \\
.090 \\
.110\end{array}$ \\
\hline
\end{tabular}
PHORUS, ORGANIC DIS- DIS- DISTOTAL TOTAL SOLVED SOLVED (MG/L (MG/L (UG/L (UG/L AS P) AS C) AS AS) AS BA) SOLVED (UG/L AS CD)
CHRO-

MIUM, COPPER, IRON, $\begin{array}{lll}\text { MIS- } & \text { DIS- } & \text { DIS- } \\ \text { SOLVED } & \text { SOLVED } & \text { SOLVED }\end{array}$ (UG/L (UG/L (UG/L

DATE

$\begin{array}{ll}\text { (MG/L } & \text { (MG/L } \\ \text { AS N) } & \text { AS N) }\end{array}$

$\begin{array}{rrrrrr}2.20 & 0.320 & 45 & 1 & 31 & <1 \\ 2.00 & .100 & 27 & -- & -- & -\overline{1} \\ 3.50 & .120 & 41 & 1 & 12 & -- \\ 1.30 & .530 & 35 & -- & -- & - \\ 1.50 & .060 & 25 & -- & -- & <1 \\ .78 & .040 & 9.4 & 1 & 19 & \\ 1.40 & .730 & 27 & -- & -- & -- \\ 1.30 & .280 & 13 & -- & -- & -- \\ 2.30 & .270 & 31 & -- & -- & -- \\ .79 & .050 & 5.5 & -- & -- & --\end{array}$

0.28

.19 
Table 6.--Water-qual1ty data for Barton Creek at Loop 360, Austin (station 08155300)--Continued

DATE

OCT., 1981

$06 \ldots \ldots$

$06 . . . .$.

$06 . . . .$.

$06 . . . .$.

$07 . . .0$

MAY , 1982

$13 \ldots . .$.

$13 \ldots .$.

$14 . \ldots$.

\begin{tabular}{|c|c|c|c|c|c|}
\hline & $\begin{array}{l}\text { MANGA- } \\
\text { NESE, }\end{array}$ & MERCU & $\begin{array}{l}\text { SELE- } \\
\text { NIUM, }\end{array}$ & SILVER, & \\
\hline $\begin{array}{l}\text { SOLVED } \\
\text { (UG/L } \\
\text { AS PB) }\end{array}$ & $\begin{array}{l}\text { SOLVED } \\
\text { (UG/L } \\
\text { AS MN) }\end{array}$ & $\begin{array}{l}\text { SOLVED } \\
\text { (UG/L } \\
\text { AS HG) }\end{array}$ & $\begin{array}{l}\text { SOLVED } \\
\text { (UG/L } \\
\text { AS SE) }\end{array}$ & $\begin{array}{l}\text { SOLVED } \\
\text { (UG/L } \\
\text { AS AG) }\end{array}$ & $\begin{array}{l}\text { SOLVED } \\
\text { (UG/L } \\
\text { AS } Z N)\end{array}$ \\
\hline
\end{tabular}

\begin{tabular}{|c|c|c|c|c|}
\hline 1 & $<1$ & 0.0 & 0 & 0 \\
\hline 2 & $\overline{1}$ & .0 & $\overline{0}$ & $\overline{0}$ \\
\hline$\cdots$ & $\cdots$ & -- & $\cdots$ & -- \\
\hline 6 & $<1$ & .0 & 0 & 0 \\
\hline & - & -- & -- & -- \\
\hline & $\cdots$ & $\overline{-}$ & - & $\overline{-}$ \\
\hline & 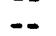 & $\therefore$ & - & $=$ \\
\hline
\end{tabular}


Table 7.- -Water-quality data for selected wells in the recharge zone

(UMHOS, micromhos per centimeter at $25^{\circ}$ Celsius; DEG C, degrees Celsius; COLS./100 ML, colonies per 100 millimeters; MG/L, milligrams per liter; UG/L, micrograms per liter; $K$, non-ideal colony count)

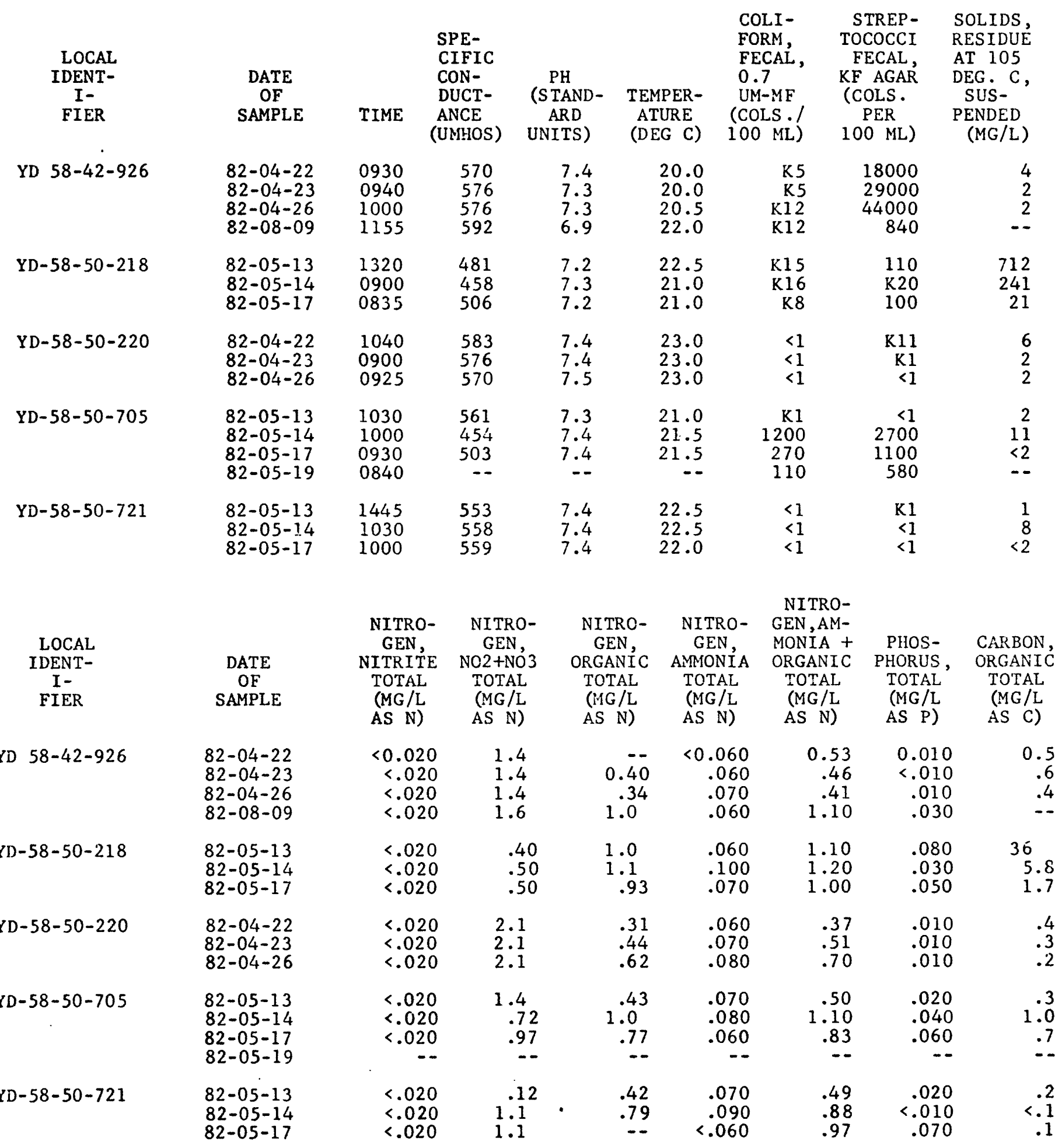


Table 7.--Water-quality data for selected wells in the recharge zone--Continued

\begin{tabular}{|c|c|c|c|c|c|c|c|}
\hline $\begin{array}{l}\text { LOCAL } \\
\text { IDENT- } \\
\text { I- } \\
\text { FIER }\end{array}$ & $\begin{array}{c}\text { DATE } \\
\text { OF } \\
\text { SAMPLE }\end{array}$ & $\begin{array}{c}\text { ARSENIC } \\
\text { DIS- } \\
\text { SOLVED } \\
\text { (UG/L } \\
\text { AS AS) }\end{array}$ & $\begin{array}{l}\text { BARIUM, } \\
\text { DIS- } \\
\text { SOLVED } \\
\text { (UG/L } \\
\text { AS BA) }\end{array}$ & $\begin{array}{c}\text { CADMIUM } \\
\text { DIS- } \\
\text { SOLVED } \\
\text { (UG/L } \\
\text { AS CD) }\end{array}$ & $\begin{array}{l}\text { CHRO- } \\
\text { MIUM, } \\
\text { DIS- } \\
\text { SOLVED } \\
\text { (UG/L } \\
\text { AS CR) }\end{array}$ & $\begin{array}{l}\text { COPPER, } \\
\text { DIS- } \\
\text { SOLVED } \\
\text { (UG/L } \\
\text { AS CU) }\end{array}$ & $\begin{array}{l}\text { IRON, } \\
\text { DIS- } \\
\text { SOLVED } \\
\text { (UG/L } \\
\text { AS FE) }\end{array}$ \\
\hline YD $58-42-926$ & $\begin{array}{l}82-04-22 \\
82-04-23 \\
82-04-26 \\
82-08-09\end{array}$ & $\begin{array}{r}<1 \\
1 \\
1 \\
--\end{array}$ & $\begin{array}{l}200 \\
200 \\
200 \\
--\end{array}$ & $\begin{array}{l}<1 \\
<1 \\
<1 \\
--\end{array}$ & $\begin{array}{l}<10 \\
<10 \\
<10 \\
--\end{array}$ & $\begin{array}{r}9 \\
19 \\
10 \\
--\end{array}$ & $\begin{array}{r}30 \\
<10 \\
30 \\
--\end{array}$ \\
\hline$Y D-58-50-218$ & $\begin{array}{l}82-05-13 \\
82-05-14 \\
82-05-17\end{array}$ & $\begin{array}{l}1 \\
1 \\
1\end{array}$ & $\begin{array}{r}<100 \\
<100 \\
100\end{array}$ & $\begin{array}{l}<1 \\
<1 \\
<1\end{array}$ & $\begin{array}{l}<10 \\
<10 \\
<10\end{array}$ & $\begin{array}{r}100 \\
110 \\
33\end{array}$ & $\begin{array}{l}10 \\
30 \\
10\end{array}$ \\
\hline$Y D-58-50-220$ & $\begin{array}{l}82-04-22 \\
82-04-23 \\
82-04-26\end{array}$ & $\begin{array}{l}1 \\
1 \\
1\end{array}$ & $\begin{array}{l}100 \\
100 \\
100\end{array}$ & $\begin{array}{l}<1 \\
<1 \\
<1\end{array}$ & $\begin{array}{l}<10 \\
<10 \\
<10\end{array}$ & $\begin{array}{l}5 \\
5 \\
2\end{array}$ & $\begin{array}{r}<10 \\
<10 \\
50\end{array}$ \\
\hline YD-58-50-705 & $\begin{array}{l}82-05-13 \\
82-05-14 \\
82-05-17 \\
82-05-19\end{array}$ & $\begin{array}{r}1 \\
1 \\
1 \\
--\end{array}$ & $\begin{array}{r}<100 \\
100 \\
<100 \\
--\end{array}$ & $\begin{array}{l}<1 \\
<1 \\
<1 \\
--\end{array}$ & $\begin{array}{l}<10 \\
<10 \\
<10 \\
--\end{array}$ & $\begin{array}{r}3 \\
5 \\
2 \\
--\end{array}$ & $\begin{array}{l}20 \\
30 \\
10 \\
--\end{array}$ \\
\hline YD- $58-50-721$ & $\begin{array}{l}82-05-13 \\
82-05-14 \\
82-05-17\end{array}$ & $\begin{array}{l}1 \\
1 \\
1\end{array}$ & $\begin{array}{r}100 \\
200 \\
<100\end{array}$ & $\begin{array}{l}<1 \\
<1 \\
<1\end{array}$ & $\begin{array}{l}<10 \\
<10 \\
<10\end{array}$ & $\begin{array}{l}2 \\
3 \\
2\end{array}$ & $\begin{array}{l}30 \\
10 \\
20\end{array}$ \\
\hline $\begin{array}{l}\text { LOCAL } \\
\text { IDENT- } \\
\text { I- } \\
\text { FIER }\end{array}$ & $\begin{array}{c}\text { DATE } \\
\text { OF } \\
\text { SAMPLE }\end{array}$ & $\begin{array}{l}\text { LEAD, } \\
\text { DIS- } \\
\text { SOLVED } \\
\text { (UG/L } \\
\text { AS PB) }\end{array}$ & $\begin{array}{l}\text { MANGA- } \\
\text { NESE, } \\
\text { DIS- } \\
\text { SOLVED } \\
\text { (UG/L } \\
\text { AS MN) }\end{array}$ & $\begin{array}{c}\text { MERCURY } \\
\text { DIS- } \\
\text { SOLVED } \\
\text { (UG/L } \\
\text { AS HG) }\end{array}$ & $\begin{array}{l}\text { SELE- } \\
\text { NIUH, } \\
\text { DIS- } \\
\text { SOLVED } \\
\text { (UG/L } \\
\text { AS SE) }\end{array}$ & $\begin{array}{c}\text { SILVER, } \\
\text { DIS- } \\
\text { SOLVED } \\
\text { (UG/L } \\
\text { AS AG) }\end{array}$ & $\begin{array}{l}\text { ZINC, } \\
\text { DIS- } \\
\text { SOLVED } \\
\text { (UG/L } \\
\text { AS ZN) }\end{array}$ \\
\hline YD 58-42-926 & $\begin{array}{l}82-04-22 \\
82-04-23 \\
82-04-26 \\
82-08-09\end{array}$ & $\begin{array}{r}2 \\
1 \\
3 \\
--\end{array}$ & $\begin{array}{l}<10 \\
<10 \\
<10 \\
--\end{array}$ & $\begin{array}{r}<0.1 \\
<.1 \\
<.1 \\
-.-\end{array}$ & $\begin{array}{l}<1 \\
<1 \\
<1 \\
--\end{array}$ & $\begin{array}{l}<1 \\
<1 \\
<1 \\
--\end{array}$ & $\begin{array}{c}420 \\
320 \\
470 \\
--\end{array}$ \\
\hline YD $-58-50-218$ & $\begin{array}{l}82-05-13 \\
82-05-14 \\
82-05-17\end{array}$ & $\begin{array}{l}24 \\
40 \\
20\end{array}$ & $\begin{array}{l}<10 \\
<10 \\
<10\end{array}$ & $\begin{array}{l}<.1 \\
.1 \\
<.1\end{array}$ & $\begin{array}{l}<1 \\
<1 \\
<1\end{array}$ & $\begin{array}{l}<1 \\
<1 \\
<1\end{array}$ & $\begin{array}{l}260 \\
260 \\
100\end{array}$ \\
\hline$Y D-58-50-220$ & $\begin{array}{l}82-04-22 \\
82-04-23 \\
82-04-26\end{array}$ & $\begin{array}{l}<1 \\
<1 \\
<1\end{array}$ & $\begin{array}{l}<10 \\
<10 \\
<10\end{array}$ & $\begin{array}{l}<.1 \\
<.1 \\
<.1\end{array}$ & $\begin{array}{r}1 \\
<1 \\
1\end{array}$ & $\begin{array}{l}<1 \\
<1 \\
<1\end{array}$ & $\begin{array}{l}20 \\
10 \\
10\end{array}$ \\
\hline$Y D-58-50-705$ & $\begin{array}{l}82-05-13 \\
82-05-14 \\
82-05-17 \\
82-05-19\end{array}$ & $\begin{array}{l}<1 \\
<1 \\
10 \\
--\end{array}$ & $\begin{array}{r}<10 \\
<10 \\
10 \\
--\end{array}$ & $\begin{array}{l}<.1 \\
<.1 \\
<.1 \\
-.-\end{array}$ & $\begin{array}{l}<1 \\
<1 \\
<1 \\
--\end{array}$ & $\begin{array}{l}<1 \\
<1 \\
<1 \\
--\end{array}$ & $\begin{array}{r}120 \\
110 \\
140 \\
--\end{array}$ \\
\hline$Y D-58-50-721$ & $\begin{array}{l}82-05-13 \\
82-05-14 \\
82-05-17\end{array}$ & $\begin{array}{r}<1 \\
2 \\
<1\end{array}$ & $\begin{array}{l}<10 \\
<10 \\
<10\end{array}$ & $\begin{array}{l}<.1 \\
<.1 \\
<.1\end{array}$ & $\begin{array}{l}<1 \\
<1 \\
<1\end{array}$ & $\begin{array}{l}<1 \\
<1 \\
<1\end{array}$ & $\begin{array}{l}10 \\
30 \\
10\end{array}$ \\
\hline
\end{tabular}

